\title{
MEKANISME TRANSMISI GONCANGAN HARGA MINYAK DAN HARGA PANGAN DUNIA TERHADAP PEREKONOMIAN MAKRO INDONESIA: PENDEKATAN STRUCTURAL VECTOR AUTOREGRESSIVE (SVAR)
}

\author{
Abdul Khaliq \\ Fakultas Ekonomi, Universitas Andalas \\ khaliq@fekon.unand.ac.id
}

\begin{abstract}
This study examines the transmission channels of oil and food price shocks to selected Indonesian macroeconomic variables including Indonesia industrial production index, world interest rate, inflation, domestic interest rate, real effective exchange rate, and Jakarta Composite Index using monthly data over the period 2001M01-2013M08. An empirical analysis is carried out by utilizing structural vector autoregressive (SVAR) framework. Impulse response functions (IRFs) and forecast variance decompositions (FEVDs) are employed to track the impact of oil and food price shock to Indonesian economy. The empirical findings of IRFs suggest that oil price shock negatively affects industrial production, depreciates real effective exchange rate, increases inflation and interest rate, and negatively affects aset price. However, following food price shocks, industrial production increases, depreciates real effective exchange rate, increase stock return. Moreover, inflation and interest rate respond positively following food price shocks. The FEVDs results clearly reveals that the variation in industrial production growth, inflation, interest rate, real effective exchange rate, and aset price due to oil price shock is relatively larger than the food price shocks. This implies that oil price is most important source of disturbances in Indonesian macroeconomy. As a whole, this study recommend that world oil and food price should be considered for policy analysis and forecasting an Indonesian macroeconomy.
\end{abstract}

Key Words : Oil and food price shocks, SVAR, IRFs, FEVDs, Indonesia 


\begin{abstract}
Abstrak
Tulisan ini menganalisis mekanisme transmisi goncangan harga minyak dan pangan dunia terhadap variabel makroekonomi Indonesia terpilih seperti pertumbuhan produksi industri, tingkat bunga dunia, inflasi, tingkat bunga domestik, kurs riil, dan saham menggunakan data bulanan periode 2001M01-2013M08. Analisis empiris memanfaatkan kerangka structural vector autoregressive (SVAR). Impulse response functions (IRFs)and forecast variance decompositions (FEVDs)digunakan untuk menelusuri dampak goncangan harga minyak dan pangan dunia terhadap perekonomian Indonesia. Temuan empiris IRFs memperlihatkan dampak negatif goncangan harga minyak dunia terhadap pertumbuhan produksi industri, mendepresiasi nilai tukar riil, meningkatkan inflasi dan tingkat bunga domestik, dan menurunkan harga aset. Sementara, dampak goncangan harga pangan dunia meningkatkan pertumbuhan produksi industri, mendepresiasi nilai tukar riil, dan meningkatkan harga saham. Sebaliknya, inflasi dan tingkat bunga merespon secara positif. Lebih lanjut, FEVDs mengungkapkan variasi pertumbuhan produksi industri, inflasi, tingkat bunga, nilai tukar riil, dan harga aset lebih besar disebabkan oleh gooncangan harga minyak dibandingkan harga pangan dunia. Temuan ini menyiratkan bahwa harga minyak dunia lebih penting sebagai sumber gangguan dalam perekonomian makro Indonesia. Secara keseluruhan tulisan ini merekomendasikan pentingnya mempertimbangkan harga minyak dan pangan dunia dalam analisis kebijakan dan prediksi makro ekonomi Indonesia.
\end{abstract}

\section{PENDAHULUAN}

Mayoritas perekonomian negaranegara di dunia mengalami dampak fluktuasi goncangan eksternal (external shock) sebagai implikasi dari globalisasi ekonomi. Sumber dari goncangan eksternal berbeda-beda dan memberikan dampak berbeda-beda pula antar negara karena memiliki karakteristik ekonomi yang berbeda. Indonesia yang memiliki karakteristik perekonomian kecil terbuka (smallopen economy) sangat sulit mengelak dari dampak goncangan eksternal. Oleh karena itu, goncangan eksternal ini menjadi fokus perhatian para pengambil kebijakan ekonomi dan para akademisi di berbagai negara di belahan dunia termasuk di Indonesia.
Goncangan ekonomi eksternal dapat bersumber dari perubahan penawaran aggregat (supply shock) seperti fluktuasi harga minyak dan volatilitas harga pangan dunia, perubahan permintaan aggregat (demand shock) seperti pengetatan kebijakan moneter, dan goncangan ekonomi dalam negeri (internal shock). Terjadinya goncangan eksternal ini jelas akan berdampak pada stabilitas perkonomian makro Indonesia. Bila terjadi goncangan penawaran agregat yang makin memburuk tanpa dibarengi oleh peningkatan permintaan agregat domestik maka Indonesia akan menghadapi ancaman pertumbuhan yang melambat bersamaan dengan terjadinya inflasi (atau disebut 
stagflasi). Stagflasi merupakan ancaman serius bagi stabilitas makro ekonomi.

\section{Karakteristik perekonomian} Indonesia kecil terbuka sangat sensitif terhadap dampak goncangan eksternal khususnya harga minyak dan harga pangan. Apalagi Indonesia mempunyai ketergantungan pada minyak dan pangan yang bersumber dari luar negeri. Selama periode 2000-2012, Indonesia telah mengimpor minyak bumi rata-rata 110,6 juta barrel per tahun (Ditjen Migas, 2013). Kondisi ini terus berlanjut di tahun 2013 dimana impor migas Indonesia selama bulan Januari hingga September telah mencapai US\$ 2,663 miliar, naik $8,51 \%$ dibandingkan periode yang sama tahun 2012. Sementara itu, di tahun 2012, impor pangan ${ }^{1}$ Indonesia sepertiberas mencapai 1,8 juta ton dengan nilai US\$ 945,6 juta, jagung sebesar 1,7 juta ton dengan nilai US\$ 501,9 juta, kedelai sebesar 1,9 juta ton dengan nilai US\$ 1,2 miliar, biji gandum dan meslin mencapai 6,3 juta ton dengan nilai US\$ 2,3 miliar, tepung terigu sebanyak 479,7 ribu ton dengan nilai US\$ 188,8 juta, dan impor gula pasir sebanyak 91,1 ribu ton
${ }^{1}$ http://www.asiabusinessinfo.com/bahanpangan-yang-terus-di-impor/ diakses 15 Desember 2013 dengan nilai US\$ 62 juta. Secara total impor pangan Indonesia di tahun 2012 telah mempunyai nilai lebih dari Rp. 80 triliun. Kondisi ini mengimplikasikan bahwa Indonesia rentan terhadap gejolak eksternal harga minyak bumi dan pangan.

Bercermin pada fakta di atas, Indonesia sangat perlu memahami fluktuasi goncangan eksternal seperti harga minyak bumi dan harga pangan dunia. Jika salah mengantisipasi dampak goncangan eksternal, Indonesia akan berhadapan dengan ancaman instabilitas ekonomi. Upaya mengantisipasi dan meredam dampak negatif goncangan eksternal memerlukan kebijakan makro yang efektif dan efisien. Kebijakan makro yang efektif dan efisien sangat penting untuk menjaga stabilitas makro ekonomi seperti mendorong pertumbuhan ekonomi dan pencapaian kesejahteraan dan kemakmuran masyarakat. Kebijakan makro yang efektif dan efisien hanya mungkin dihasilkan dari pengetahuan yang baik tentang mekanisme transmisi dampak goncangan eksternal terutama dampak fluktuasi harga minyak dan harga pangan terhadap perekonomian makro Indonesia. Untuk mengetahui mekanisme transmisi dampak 
goncangan eksternal harga minyak dan pangan dunia diperlukan kajian yang spesifik dengan metode yang spesifik pula.

Salah satu metode yang berkembang pesat dewasa ini dalam menganalisis mekanisme transmisi dampak goncangan eksternal seperti harga minyak dan harga pangan dunia adalah pendekatan structural vector autoregressive (S-VAR). Metode ini telah banyak diadopsi oleh para peneliti dan akademisi di dunia untuk menguji mekanisme transmisi kejutan harga minyak dunia terhadap perekonomian makro (seperti Yahya, 2007; Tang et al., 2010; Rydland, 2011), namun hanya sedikit yang menguji secara bersamaan dampak fluktuasi harga minyak dan volatilitas harga pangan dunia terhadap perekonomian makro diantaranya Alom, et al. (2013) dan Hakro dan Omezzine (2010). Sementara untuk kasus Indonesia belum ada yang menganalisis dampak harga minyak dan pangan dunia secara bersamaan terhadap perekonomian makro Indonesia $^{2}$. Oleh karena itu, tulisan ini menjadi sangat penting dalam pengembangan literatur dan temuan

\footnotetext{
${ }^{2}$ Kebanyakan studi kasus Indonesia melacak dampak goncangan harga minyak, diantaranya Yahya (2007) danNizar (2012).
}

empiris di Indonesia sebagai bagian langkah esensial dalam memformulasi kebijakan makro dalam upaya meredam dampak negatif dari goncangan eksternal seperti fluktuasi harga minyak dan volatilitas harga pangan dunia.

\section{TINJAUAN KEPUSTAKAAN}

\section{Dampak Goncangan Harga Minyak}

\section{Dunia Terhadap Makroekonomi}

Dampak goncangan harga minyak dunia telah menjadi kajian para peneliti dan ekonom semenjak tahun 1970-an. Salah satu publikasi pertama dalam menganalisis kejutan harga minyak terhadap US GNP potensial adalah Rasche dan Tatom (1977). Kejutan harga minyak telah menjadi salah satu argumen bagi perlambatan perekonomian global terutama bagi negara importir minyak (Hamilton, 1983; Hamilton, 1996; Hamilton, 2003; dan Hamilton, 2009). Studi Hamilton (1983) telah menjadi pendahulu bagi kajian dampak harga minyak terhadap kegiatan perekonomian makro didunia. Dengan menggunakan pendekatan VectorAutoregressive (VAR) yang dikembangkan oleh Sim (1980) untuk data US pada periode 1948-1980, Hamilton (1983) menemukan korelasi 
yang erat antara harga minyak dan pertumbuhan GNP USA.

Mengikuti studi Hamilton (1983), berbagai penelitian telah banyak mendokumentasikan dampak kenaikan harga minyak terhadap perekonomian Amerika Serikat (Gisser dan Goodwin, 1986; Mork, 1989; Lee, et al., 1995; Blanchard and Gali, 2007; Balke, et al, 2010). Bahkan beberapa studi memfokuskan pada dampak harga minyak dunia dalam kerangka struktur pasar (Rotemberg dan Woodford, 1996; Finn, 2000). Rotemberg dan Woodford (1996) menemukan bahwa, dalam skenario pasar persaingan tidak sempurna, kenaikan 1 persen harga minyak berkontribusi pada penurunan 0,25 persen output dan 0,09 upah riil. Temuan ini didukung pula oleh Finn (2000) yang melakukan kajian pasar persaingan sempurna dimana terungkap dampak negatif kenaikan harga minyak terhadap aktivitas perekonomian makro. Dari kedua studi ini terlihat bahwa kenaikan harga minyak berdampak negatif pada efektivitas ekonomi baik pada pasar persaingan sempurna maupun pasar persaingan tidak sempurna.
Selain berbasis struktur pasar, para peneliti juga melakukan studi dampak kenaikan harga minyak terhadap perekonomian sektoral (Keane dan Prasad, 1996; Davis dan Haltiwanger, 2001; Lee dan Ni, 2002; dan Lippi dan Nobili, 2009). Keane dan Prasad (1996) menemukan fakta bahwa kenaikan harga minyak berdampak negatif pada upah riil. Sementara itu, Davis dan Haltiwanger (2001) menggambarkan kejutan harga minyak memainkan peran penting dalam fluktuasi penciptaan lapangan pekerjaan pada jangka pendek. Bahkan mereka menemukan, untuk data US tahun 1972-1988, dampak kenaikan harga minyak dua kali lipat dari dampak kejutan moneter. Selanjutnya, studi Lee dan Ni (2002) melaporkan kenaikan harga minyak memiliki dampak jangka pendek pada output dari industri. Kenaikan harga minyak mengurangi penawaran industri yang menggunakan minyak secara intensif dan menurunkan permintaan terhadap output dari industri seperti mobil. Studi yang sama dilakukan oleh Lippi dan Nobili (2009). Mereka menemukan dampak negatif kejutan penawaran harga minyak terhadap output US dan dampak positif permintaan minyak pada GDP. 
Beberapa studi lainnya mengkaji besaran dan kekuatan dampak kejutan harga minyak. Salah satu diantaranya adalah studi yang dilakukan oleh Burbidge dan Harrison (1984). Dengan menggunakan pendekatan VAR, Burbidge dan Harrison (1984) mengungkapkan dampak goncangan harga minyak terhadap variabel perekonomian makro di negara OECD. Mereka menemukan dampak harga minyak yang berbeda untuk periode 1973-74 dan 1979-80. Dampak harga minyak periode 1973-74 terlihat nyata pada variable makroekonomi. Temuan ini diperkuat pula oleh hasil penelitian Blanchard dan Gali (2007).

Studi literatur yang didiskusikan di atas mendiskusikan temuan di US, tetapi banyak pula yang menganalisis dampak harga minyak dunia terhadap perekonomian makro di berbagai negara belahan dunia lainnya. Salah satunya adalah Cunado dan Gracia (2003) yang menganalisis perilaku harga minyak dan perubahan GDP di beberapa negara Eropa menggunakan pendekatan cointegrating VAR. Mereka menemukan fakta dampak negatif harga minyak terhadap kegiatan perekonomian makro. Dengan menggunakan pendekatan FactorAugmented Vector autoregressive
(FAVAR), Lescaroux dan Mignon (2009) menggambarkan hubungan positif antara harga minyak dengan CPI, PPI dan tingkat bunga dan hubungan negatif antara kejutan harga minyak dengan output, konsumsi dan investasi di China. Penggunaan Structural-VAR (SVAR) oleh Tang et al. (2010) mendukung temuan untuk China dimana terlihat dampak negatif harga minyak terhadap output dan investasi dan berdampak positif terhadap inflasi dan tingkat bunga. Sementara itu, Zhange dan Reed (2008) menemukan adanya dampak asimetris dari goncangan harga minyak dunia terhadap pertumbuhan ekonomi Jepang.

\section{Dampak Fluktuasi Harga Pangan Dunia Terhadap Makroekonomi}

Selain dampak kejutan harga minyak, kenaikan harga pangan selama tahun 1970-an juga telah menciptakan krisis yang mendorong peningkatan kelaparan diberbagai belahan dunia. Walaupun demikian, studi dampak kejutan harga pangan dunia terhadap perekonomian makro tidak seintensif kajian dampak harga minyak. Diantara studi yang menganalisis dampak harga pangan dunia terhadap perekonomian makro adalah studi yang dilakukan oleh Abott et al (2009), Aksoy dan Ng 
(2008), von Braun (2008) dan Galesi dan Lombardi (2009). Abott et al (2009) menemukan dampak kenaikan harga makanan terhadap depresiasi USD, perubahan konsumsi, produksi dan pertumbuhan bio-fuel.

Sedangkan Aksoy dan Ng (2008) melakukan kajian harga pangan terhadap negara net-importir pangan. Mereka menemukan bahwa kejutan harga pangan berdampak negatif pada neraca perdagangan pangan negara berpendapatan rendah dan berdampak positif pada neraca perdagangan negara berpendapatan menengah. Penelitian von Braun (2008) mengungkapkan kenaikan harga pangan berdampak pada negara netimportir pangan. Sementara itu, Galesi dan Lombardi (2009) menyatakan dampak inflasi dari kenaikan harga pangan terhadap negara maju dan kejutan kenaikan harga pangan hanya pada negera yang sedang berkembang.

Selanjutnya Headey dan Fan (2008) melakukan studi anatomi krisis penyebab dan dampak dari harga pangan dunia. Mereka menemukan fakta bahwa terdapat mekanisme transmisi harga pangan dalam apresiasi nilai tukar terhadap US Dollar. Kenaikan harga pangan dapat ditransmisikan langsung pada pangan yang diimpor, sedangkan negara pengekspor pangan juga merasakan dampak kenaikan harga pangan karena harga yang mereka hadapi sebagian dapat mempengaruhi harga pangan dunia. Sedangkan studi Aksoy dan $\mathrm{Ng}$ (2008) melihat neraca perdagangan negara kurang berkembang sedikit terpengaruh oleh goncangan harga pangan dunia dibandingkan dengan dampak goncangan harga minyak dunia.

Studi harga pangan terhadap perekonomian makroekonomi juga telah menarik perhatian Apergis dan Rezitis (2011). Menggunakan metode GARCH dan GARCH-X, mereka menguji dampak volatilitas perilaku harga pangan dan potensi penyimpangan jangka pendek terhadap perekonomian makro Yunani. Hasil studi model GARCH-X $(1,1)$ memperlihatkan dampak positif signifikan deviasi pada volatilitas harga pangan terhadap variable makroekonomi seperti kesimbangan uang riil, pendapatan perkapita, nilai tukar riil, rasio defisit terhadap pendapatan riil.

Mekanisme Transmisi Kejutan Harga Minyak dan Pangan Dunia 
Dari diskusi teoritis dan empiris dampak goncangan harga minyak dan pangan dunia terhadap perekonomian makro sebelumnya terlihat bahwa kejutan harga minyak dan harga pangan dunia terhadap perekonomian makro melalui berbagai mekanisme transmisi. Mekanisme transmisi yang dimaksud termasuk dampak sisi penawaran, transfer pendapatan dari negara importir minyak dan pangan ke negara eksportir minyak dan pangan dunia, dampak keseimbangan riil, kebijakan moneter, inflasi, konsumsi, investasi, dan harga saham (diantaranya Brown dan Yocel, 2002; Lardic dan Mignon, 2008; Jones et al., 2004; Tang et al., 2010; Alom, et al. 2013). Gambar 1 memperlihatkan mekanisme transmisi kejutan harga minyak dan pangan dunia terhadap variabel makroekonomi.

Berdasarkan gambar 1 mekanisme transmisi kejutan harga minyak dan pangan menyiratkan bahwa kejutan harga minyak dan pangan dunia mendorong perlambatan pertumbuhan ekonomi dunia (Headey dan Fan, 2008, Abott et al., 2009, Galesi dan Lombardi, 2009; Alom, et al. 2013). Kenaikan harga minyak dan pangan mendorong kenaikan pembayaran negara importir sehingga menurunkan ekspor bersih dan menyebabkan penurunan output domestik. Kenaikan harga minyak dan pangan juga meningkatkan permintaan uang dan tingkat bunga yang memproduksi dampak berlawanan dengan nilai tukar.

Dampak mekanisme transmisi harga pangan dan minyak dunia merubah harga domestik melalui beberapa saluran, antara lain: 1) dampak langsung berupa kenaikan harga produk domestik; 2) dampak tidak langsung terhadap harga produk yang berhubungan dengan biaya produksi; 3) dampak selanjutnya berupa kenaikan biaya hidup dan upah rill tenaga kerja (Galesi dan Lombardi, 2009). Dampak 1 dan 2 merupakan dampak jangka pendek ke jangka menengah, sedangkan dampak 3 merupakan jangka panjang yang dapat mendorong percepatan inflasi (Galesi dan Lombardi, 2009). Setelah kenaikan harga minyak dan pangan, otoritas moneter mengadopsi kebijakan moneter ekspansif sehinga memicu inflasi (Galesi dan Lombardi, 2009; Bruno dan Sach, 1985). 


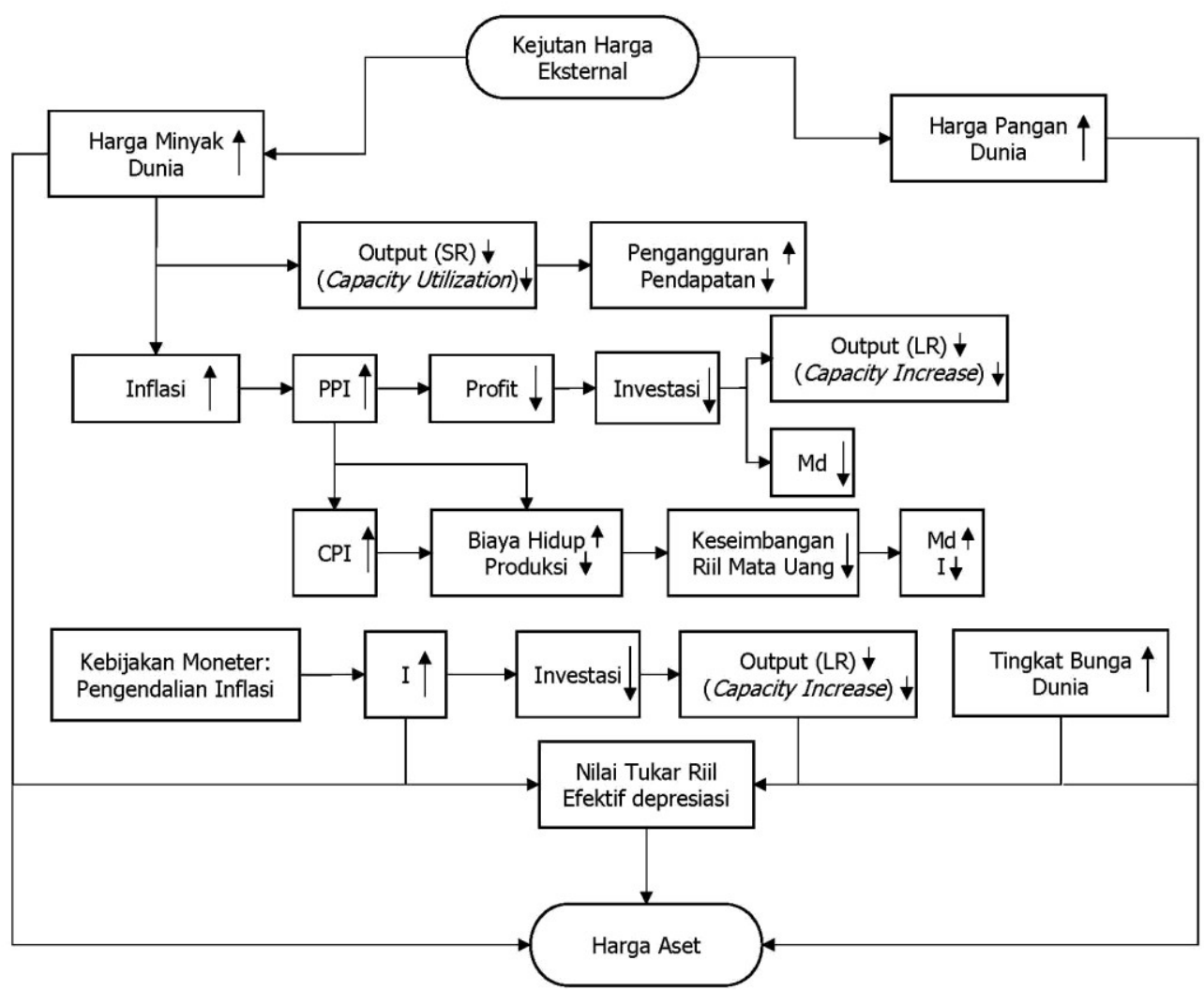

Sumber: Dikonstruksi dari Tang et al. (2010) dan Alom (2013)

Selanjutnya studi Dimitrova (2005) menemukan bahwa kenaikan harga minyak membuat nilai tukar terdepresiasi sehingga ekspektasi inflasi meningkat. Bank sentral sebagai otoritas moneter akan mengendalikan ekspektasi inflasi melalui kebijakan moneter kontraktif dengan menaikkan suku bunga nominal (Mankiw, 2013). Kenaikan suku bunga nominal akan mempengaruhi tingkat bunga di instrumen obligasi (Miskhin, 2001). Kondisi ini menurunkan harga aset (saham) karena instrumen obligasi menjadi jauh lebih diminati dan beresiko rendah karena tingkat pengembaliannya ditentukan oleh tingkat suku bunga (Basher dan Sadorsky, 2006; Adebiyi et al., 2009).

\section{METODE PENELITIAN}

\section{Spesifikasi Model S-VAR Indonesia}

Penelitian ini memanfaatkan small structural vector autoregression model yang dikembangkan oleh Kim dan Roubini (1999) dengan 
mempertimbangkan model yang Zealand, South Korea, Singapore, dimodifikasi oleh Alom, et al. (2013) dalam meneliti negara-negara di Asia dan Pasifik, seperti Australia, New Hong Kong, Taiwan, India dan Thailand. Model SVAR yang terbentuk untuk Indonesia adalah:

$$
\begin{aligned}
& R O P_{t}=A_{1} x_{t-1}+\cdots+A_{p} x_{t-p}+u_{1 t} \\
& W P I_{t}=c_{2} R O P_{t}+A_{1} x_{t-1}+\cdots+A_{p} x_{t-p}+u_{2 t} \\
& I P G_{t}=c_{4} R O P_{t}+c_{5} W P I_{t}+A_{1} x_{t-1}+\cdots+A_{p} x_{t-p}+u_{3 t} \\
& I N F_{t}=c_{7} R O P_{t}+c_{8} W P I_{t}+c_{9} I P G_{t}+A_{1} x_{t-1}+\cdots+A_{p} x_{t-p}+u_{4 t} \\
& I W_{t}=c_{11} R O P_{t}+c_{12} W P I_{t}+A_{1} x_{t-1}+\cdots+A_{p} x_{t-p}+u_{5 t} \\
& I_{t}=c_{14} R O P_{t}+c_{15} W P I_{t}+c_{16} I W_{t}+A_{1} x_{t-1}+\cdots+A_{p} x_{t-p}+u_{6 t} \\
& R E E R_{t}=c_{18} R O P_{t}+c_{19} W P I_{t}+c_{20} I P G_{t}+c_{21} I N F_{t}+c_{22} I W_{t}+c_{23} I_{t} \\
& \quad+A_{1} x_{t-1}+\cdots+A_{p} x_{t-p}+u_{7 t} \\
& J C I_{t}=c_{25} R O P_{t}+c_{26} W P I_{t}+c_{27} I P G_{t}+c_{28} I N F_{t}+c_{29} I W_{t}+c_{30} I_{t} \\
& \quad+c_{31} R E E R_{t}+A_{1} x_{t-1}+\cdots+A_{p} x_{t-p}+u_{8 t}
\end{aligned}
$$

(8)Persamaan (1) hingga persamaan (8) dapat diterjemahkan ke persamaan berikut:

$$
\begin{aligned}
\varepsilon_{t}^{R O P}= & c_{1} u_{t}^{R O P} \\
\varepsilon_{t}^{W P I}= & c_{2} \varepsilon_{t}^{R O P}+c_{3} u_{t}^{W P I} \\
\varepsilon_{t}^{I P G}= & c_{4} \varepsilon_{t}^{R O P}+c_{5} \varepsilon_{t}^{W P I}+c_{6} u_{t}^{I P G} \\
\varepsilon_{t}^{I N F}= & c_{7} \varepsilon_{t}^{R O P}+c_{8} \varepsilon_{t}^{W P I}+c_{9} \varepsilon_{t}^{I P G}+c_{10} u_{t}^{I N F} \\
\varepsilon_{t}^{I W}= & c_{11} \varepsilon_{t}^{R O P}+c_{12} \varepsilon_{t}^{W P I}+c_{13} u_{t}^{I W} \\
\varepsilon_{t}^{I}= & c_{14} \varepsilon_{t}^{R O P}+c_{15} \varepsilon_{t}^{W P I}+c_{16} \varepsilon_{t}^{I W}+c_{17} u_{t}^{I} \\
\varepsilon_{t}^{R E E R}= & c_{18} \varepsilon_{t}^{R O P}+c_{19} \varepsilon_{t}^{W P I}+c_{20} \varepsilon_{t}^{I P G}+c_{21} \varepsilon_{t}^{I N F}+c_{22} \varepsilon_{t}^{I W}+c_{23} \varepsilon_{t}^{I}+c_{24} u_{t}^{R E E R} \\
\varepsilon_{t}^{J C I}= & c_{25} \varepsilon_{t}^{R O P}+c_{26} \varepsilon_{t}^{W P I}+c_{27} \varepsilon_{t}^{I P G}+c_{28} \varepsilon_{t}^{I N F}+c_{29} \varepsilon_{t}^{I W}+c_{30} \varepsilon_{t}^{I} \\
& +c_{31} \varepsilon_{t}^{R E E R}+c_{32} u_{t}^{J C I}
\end{aligned}
$$


Persamaan (9) hingga persamaan (16) dapat ditulis kembali dalam bentuk matriks mengikuti persamaan SVAR yang ditulis Hamilton (1994) sebelumnya sehingga didapatkan matriks di bawah ini:

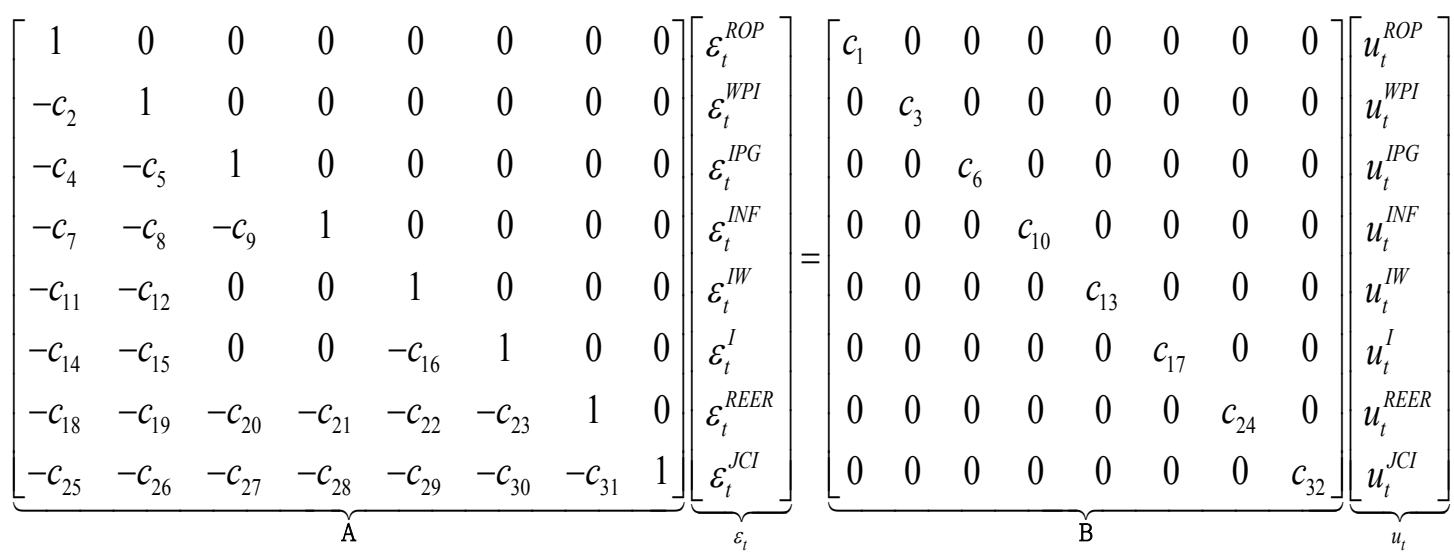

Matriks di atas mengemukakan urutan persamaan sesuai dengan tingkat endogenitas variabel ekonomi yang digunakan. Persamaan pada baris pertama memperlihatkan pengaruh shock tingkat harga minyak dunia terhadap tingkat harga minyak dunia itu sendiri (ROP). Persamaan baris kedua menunjukkan shock harga pangan dunia terhadap shock harga minyak dunia dan harga pangan dunia itu sendiri (WPI). Persamaan baris ketiga menggambarkan shock pertumbuhan produksi industri terhadap shock harga minyak dunia dan shock harga pangan dunia serta pertumbuhan produksi industri itu sendiri (IPG).
Selanjutnya, persamaan baris keempat menggambarkan shock inflasi terhadap shock harga minyak dunia, harga pangan dunia, dan pertumbuhan produksi industri serta shock inflasi itu sendiri (INF). Persamaan baris kelima memperlihatkan shock tingkat bunga dunia terhadap shock harga minyak dunia dan shock harga pangan dunia serta tingkat bunga dunia itu sendiri (IW). Persamaan baris keenam menyatakan shock tingkat bunga domestik terhadap shock harga minyak dunia, harga pangan dunia, dan shock inflasi serta shock tingkat bunga domestik itu sendiri (I).

Sementara itu, persamaan baris ketujuh menjelaskan shock nilai tukar riil efektif terhadap shock harga 
minyak dunia, harga pangan dunia, pertumbuhan produksi industri, inflasi, tingkat bunga dunia, tingkat bunga domestik dan shock nilai tukar riil efektif itu sendiri (REER). Terakhir, persamaan baris kedelapan mengilustrasikan shock harga aset terhadap shock harga minyak dunia, harga pangan dunia, pertumbuhan produksi industri, inflasi, tingkat bunga dunia, tingkat bunga domestik, nilai tukar riil efektif, dan shock harga aset itu sendiri (JCI).

Selain itu, model di atas bersifat over-identified yang terdiri lebih dari empat restriksi yang digunakan untuk mengidentifikasi model dan model ini bersifat recursive. Setelah proses iterasi, koefisien pada matriks diketahui sebagai wujud estimasi Model SVAR. Hasil estimasi diperlukan sebagai basis menganalisis innovation accounting (impulse response functions) dan factor errorvariance decompositions.

\section{Data dan Sumber Data}

Data harga minyak yang digunakan adalah West Texas Intermediate $(W T I)^{3}$. WTI merupakan benchmark minyak mentah di US.

\footnotetext{
${ }^{3}$ Ada 3 benchmark harga minyak dunia yaitu WTI, Brent Blend, and Fateh Dubai
}

Harga minyak dunia memiliki tahun dasar 2000 yang bersumber dari WTI tahun 2001M01-2013M08. Harga riil minyak dunia ditransformasi ke dalam rupiah dibagi dengan IHK dan selanjutnya ditulis dalam bentuk logaritma natural. Harga pangan dunia diukur dengan indeks harga pangan dunia memiliki tahun dasar 2000 yang bersumber dari FAO tahun 2001M012013M08. Data indeks harga pangan dunia ditransformasi ke dalam bentuk logaritma natural. Data pertumbuhan produksi industri (IPG) dalam bentuk persentase bersumber dari www.tradingeconomics.com tahun 2001M01-2013M08. Selanjutnya, data inflasi dalam bentuk persentase yang bersumber dari Badan Pusat Statistik tahun 2001M01-2013M08. Data tingkat suku bunga dunia (IW) dalam bentuk persentase dan bersumber dari Bank Indonesia tahun 2001M012013M08. Data tingkat suku bunga domestik (I) dalam bentuk persentase dan bersumber dari Bank Indonesia tahun 2001M01-2013M08. Data Nilai tukar riil efektif (REER) memiliki tahun dasar 2000 yang bersumber dari Bank of International Settlement (BIS) tahun 2001M01-2013M08 yang di bentuk logaritma natural.Data Indeks Harga Saham Gabungan (IHSG) atau Jakarta Composite Index (JCI) 
bersumber

dari

http://finance yahoo.com $/ \mathrm{q} / \mathrm{hp}$ ? $\mathrm{s}=\wedge \mathrm{JKS}$

E+Historical+Prices tahun 2001M01-

2013M08. Harga aset ditransformasi

ke dalam logaritma natural.

\section{HASIL DAN PEMBAHASAN}

\section{Uji Diagnostik}

Sebelum menganalis impulse response functions (IRFs) dan forecast error variance decompositions (FEVDs), uji diagnostik telah dilakukan melalui uji stasioneritas, penentuan panjang selang optimal, uji urutan variabel dan uji stabilitas sistem VAR/VECM/SVAR. Hasil uji stasioneritas mengungkapkan pada umumnya variabel penelitian stasioner pada first difference. Sedangkan pengujian selang optimal diperoleh pada lag 8. Temuan ini memberikan pilihan alternatif metode analisis VAR terstriksi dalam bentuk VECM atau SVAR. Dari pengujian sistem persamaan VECM terungkap hasil yang tidak stabil sehingga alternatif pilihannya adalah SVAR. Setelah menetapkan sistem SVAR, selanjutnya menguji urutan variabel dan uji stabilitas SVAR. Hasil pengujian urutan variabel terungkap bersifat over-identified sehingga tidak ada persoalan pada urutan persamaan sistem SVAR. Temuan ini didukung oleh hasil uji sistem SVAR yang telah stabil ditandai tidak adanya variabel di luar unit circle.

\section{Hasil Estimasi Model SVAR}

Estimasi model SVAR ditujukan untuk melihat arah hubungan antar variabel makro ekonomi yang diteliti ${ }^{4}$.Dari hasil estimasi memperlihatkan bahwa semua variabel penelitian memiliki hubungan positif signifikan terhadap variabelnya sendiri. Fakta ini dapat dilihat dari hubungan antara inovasi harga pangan dunia sebelumnya terhadap harga dunia saat ini. Kondisi yang sama terlihat pula pada inovasi-inovasi harga pangan dunia, pertumbuhan produksi industri, inflasi, tingkat bunga dunia, tingkat bunga domestik, nilai tukar riil efektif, dan harga aset.

Jika difokuskan pada inovasi variabel eksternal harga minyak dunia dan harga pangan dunia terhadap variabel makroekonomi Indonesia maka terlihat bahwa perubahan harga minyak memiliki arah yang berbeda-

\footnotetext{
${ }^{4}$ Hasil estimasi bukanlah alat analisis utama model VAR/VECM/SVAR karena analisis utama yang digunakan adalah analisis impulse response functions (IRFs) dan forecast error variance decompositions (FEVDs). Selain itu, hasil estimasi tidak dapat diterjemahkan langsung karena merupakan persamaan reduced formsehingga yang bisa dilihat arah hubungannya.
} 
beda terhadap masing-masing variabel makro ekonomi. Tetapi perubahan harga minyak dunia yang memiliki hubungan positif signifikan adalah terhadap tingkat bunga dunia dan tingkat bunga domestik. Sementara itu, pengaruh harga pangan dunia juga memiliki arah hubungan yang berbeda terhadap variabel makro ekonomi Indonesia. Namun, arah hubungan positif signifikan dari inovasi harga pangan dunia hanya ditemukan terhadap harga pangan dunia nilai tukar riil efektif. Hasil temuan ini memperlihatkan bahwa harga minyak dunia mempengaruhi makro ekonomi domestik melalui tingkat bunga dunia dan harga pangan dunia mempengaruhi variabel makro ekonomi domestik melalui (pass-through) nilai tukar riil efektif.

Tabel 1 Hasil Estimasi Model SVAR

\begin{tabular}{|c|c|c|c|c|c|c|c|c|}
\hline \multirow[t]{2}{*}{ Inovasi } & $\varepsilon^{R O P}$ & $\varepsilon^{W P I}$ & $\varepsilon^{I P G}$ & $\varepsilon^{I N F}$ & $\varepsilon^{I W}$ & $\varepsilon^{I}$ & $\varepsilon^{R E E R}$ & $\varepsilon^{J C I}$ \\
\hline & (1) & (2) & (3) & (4) & (5) & (6) & (7) & (8) \\
\hline ROP & $\begin{array}{c}0,097786 \\
(16,97056)^{*}\end{array}$ & $\begin{array}{c}0,039852 \\
(0,972352)\end{array}$ & $\begin{array}{c}-2,328178 \\
(-0,591416)\end{array}$ & $\begin{array}{c}-0,735964 \\
(-0,865569)\end{array}$ & $\begin{array}{c}0,371782 \\
(2,545247)^{* *}\end{array}$ & $\begin{array}{c}0,261490 \\
(1,622849) * * *\end{array}$ & $\begin{array}{c}0,015808 \\
(1,033609)\end{array}$ & $\begin{array}{c}-0,061769 \\
(-1,200838)\end{array}$ \\
\hline WPI & & $\begin{array}{c}0,048094 \\
(16,97056)^{*}\end{array}$ & $\begin{array}{c}-6,126159 \\
(-0,767887) \\
\end{array}$ & $\begin{array}{c}-2,434012 \\
(-1,411366)\end{array}$ & $\begin{array}{c}-0,450569 \\
(-1,522073) \\
\end{array}$ & $\begin{array}{c}-0,326408 \\
(-1,013692) \\
\end{array}$ & $\begin{array}{c}0,086091 \\
(2,817940)^{*}\end{array}$ & $\begin{array}{c}0,048243 \\
(0,458756) \\
\end{array}$ \\
\hline IPG & & & $\begin{array}{c}4,604254 \\
(16,97056)^{*}\end{array}$ & $\begin{array}{c}-0,006498 \\
(-0,361477)\end{array}$ & & & $\begin{array}{c}-0,000621 \\
(- \\
1,984006)^{* *}\end{array}$ & $\begin{array}{c}-0,001947 \\
(- \\
1,832115)^{* * *}\end{array}$ \\
\hline INF & & & & $\begin{array}{c}0,993262 \\
(16,97056)^{*}\end{array}$ & & & $\begin{array}{c}0,005431 \\
(3,746560)^{*}\end{array}$ & $\begin{array}{c}-0,011860 \\
(- \\
2,330565)^{* *}\end{array}$ \\
\hline IW & & & & & $\begin{array}{c}0,170842 \\
(16,97056)^{*}\end{array}$ & $\begin{array}{c}0,030742 \\
(0,341862)\end{array}$ & $\begin{array}{c}-0,012385 \\
(-1,468902)\end{array}$ & $\begin{array}{c}0,083276 \\
(2,925631)^{*}\end{array}$ \\
\hline I & & & & & & $\begin{array}{c}0,184356 \\
(16,97056)^{*}\end{array}$ & $\begin{array}{c}0,005853 \\
(0,749390) \\
\end{array}$ & $\begin{array}{c}-0,007717 \\
(-0,294281) \\
\end{array}$ \\
\hline REER & & & & & & & $\begin{array}{c}0,017278 \\
(16,97056)^{*}\end{array}$ & $\begin{array}{c}0,919087 \\
(3,291326)^{*}\end{array}$ \\
\hline JCI & & & & & & & & $\begin{array}{c}0,057899 \\
(16,97056)^{*}\end{array}$ \\
\hline
\end{tabular}

Sumber: Hasil Olahan, 2014

Catatan: Angka dalam kurung adalah hasil uji-Z

$*, * *$, dan ${ }^{* * *}$ menyatakan signifikan pada level $1 \%, 5 \%$, dan $10 \%$

Selain itu, hasil estimasi juga mengungkapkan variabel-variabel lain diluar harga minyak dan harga pangan dunia yang memiliki hubungan yang siginifkan terhadap variabel makro ekonomi Indonesia. Pertumbuhan produksi industri memiliki hubungan negatif signifikan secara statistik terhadap nilai tukar riil efektif dan harga aset. Sedangkan inovasi inflasi memiliki dampak positif siginifikan secara statistik terhadap nilai tukar efektif dan negatif signifikan secara statistik terhadap harga aset. Selanjutnya, inovasi tingkat bunga dunia dan nilai tukar riil efektif memiliki hubungan positif signifikan secara statistik terhadap harga aset. 
Mekanisme Transmisi Goncangan Harga Minyak dan Harga Pangan Dunia

Dalam model SVAR mekanisme transmisi bukanlah menjadi fokus utama analisis karena model SVAR telah merestriksi model VAR sesuai dengan hubungan teoritis sehingga hubungan mekanisme transmisi menjadi jelas. Pengungkapan mekanisme transmisi pada penelitian ini ditujukan untuk memperkuat dugaan adanya transmisi goncangan harga minyak dan harga pangan dunia terhadap variabel makro ekonomi. Walaupun dilakukan analisis mekanisme transmisi (peta hubungan), analisis utama penelitian tetap bertumpu pada analisis impulse response functions(IRFs) dan forecast error variance decompositions (FEVDs).

Pemetaan hubungan (mekanisme transimisi) dampak harga minyak dunia dan harga pangan dunia terhadap variabel makro ekonomi Indonesia menggunakan hasil VAR Causality dan Granger Causality. Peta hubungan memperlihatkan berbagai mekanisme transmisi dampak harga minyak dan harga pangan dunia terhadap variabel makro ekonomi. Secara sederhana, mekanisme transmisi harga minyak dan harga pangan dunia terhadap variabel makro ekonomi dapat terlihat dari dampak kejutan harga minyak dan pangan dunia yang mendorong nilai tukar riil terdepresiasi. Kondisi ini menyebabkan terjadinya kenaikan inflasi. 


\section{Gambar 2}

Mekanisme Transmisi Goncangan Harga Minyak dan Pangan Dunia

Terhadap Variabel Makro Ekonomi Indonesia

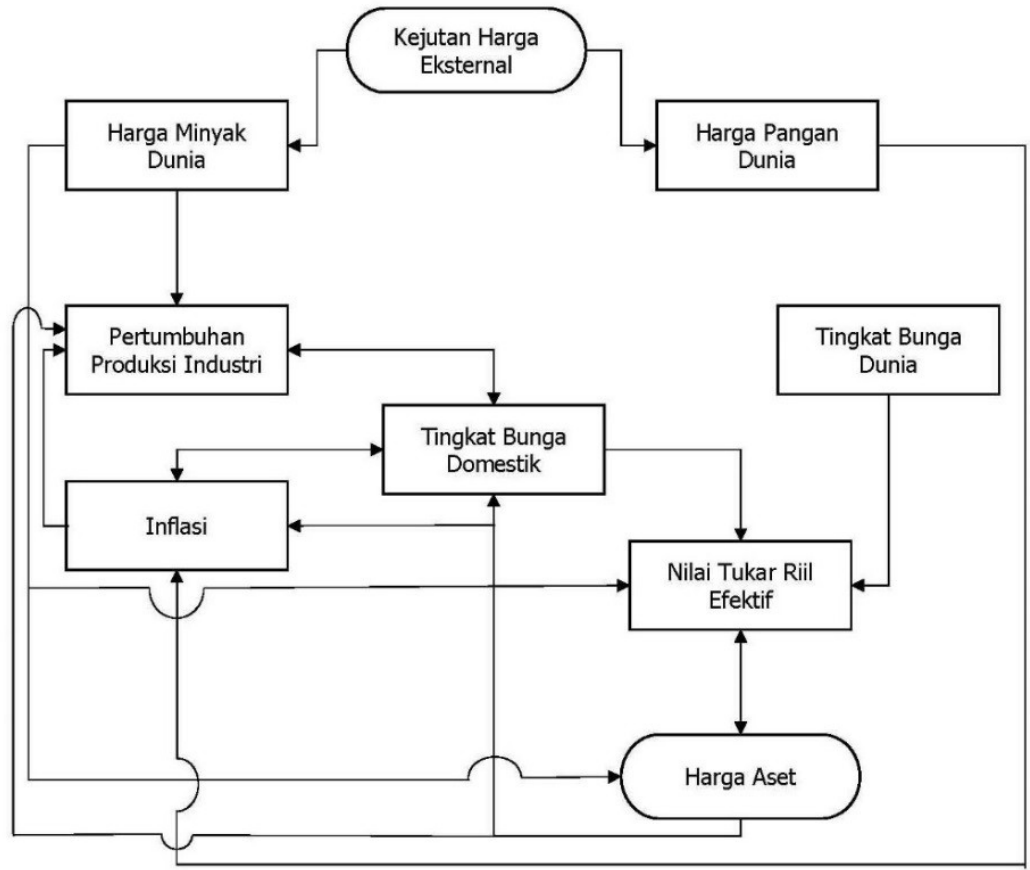

Sumber: Hasil Olahan, 2014

Sementara pada saat bersamaan kejutan harga minyak dunia dan inflasi mendorong kenaikan biaya produksi sehingga menurunkan pertumbuhan produksi industri. Kenaikan inflasi membuat bank sentral melakukan intervensi dalam bentuk kebijakan moneter kontraktif dengan menaikkan tingkat bunga. Kenaikan tingkat bunga membuat investasi pada instrumen obligasi menjadi lebih menarik dibandingkan dengan membeli saham (aset). Kondisi ini menyebabkan harga aset menjadi menurun sehingga pertumbuhan produksi industri menurun. Jika kondisi ini terus berlanjut maka kondisi pertumbuhan ekonomi Indonesia akan mengalami perlambatan. Oleh karena itu, perubahan pergerakan harga minyak dunia dan harga pangan dunia penting untuk ditelusuri. Untuk melakukan penelusuran ini dalam model SVAR maka analisis impulse response functions (IRFs) dan forecast error variance decompositions (FEVDs) menempati posisi yang sangat vital untuk dilakukan. Melalui IRFs akan terungkap respon masing-masing variabel makro ekonomi terhadap 
inovasi perubahan harga minyak dan pangan dunia. Sementara FEVDs dapat mengungkap kontribusi dari harga minyak dan pangan dunia dalam variabilitas variabel makro ekonomi Indonesia.

\section{Impulse Response Functions}

\section{Goncangan Harga Minyak Dunia}

Analisis IRFs pada bagian ini menitikberatkan pelacakan dampak goncangan harga minyak dunia (ROP) terhadap variabel-variabel makro ekonomi Indonesia seperti pertumbuhan produksi industri (IPG), tingkat bunga domestik (I), inflasi (INF), nilai tukar riil (REER), dan harga aset (JCI) merespon kejutan harga minyak (ROP). Analisis IRFs dilakukan terhadap adanya inovasi berupakan peningkatan nilai variabel sebesar satu standar deviasi pada awal periode yang mengakibatkan perubahan bulanan selama jangka waktu 3 tahun. Pemilihan jangka waktu 3 tahun diperkirakan relatif cocok untuk mengamati perubahan variabel makro ekonomi terhadap inovasi kejutan dari harga minyak dunia.

Hasil penelitian impulse response memperlihatkan dampak goncangan harga minyak dunia terhadap variabel makro ekonomi Indonesia selama 36 bulan atau 3 tahun. Dampak respon yang diterima pertumbuhan produksi industri (IPG) akibat goncangan harga minyak (Shock 1) selama 36 bulan adalah bersifat divergence. Fakta ini tunjukkan oleh grafik accumulated of IPG to shock 1. Peningkatan atau inovasi harga minyak dunia direspon oleh menurunnya pertumbuhan produksi industri di Indonesia secara terus menerus selama 3 tahun. Titik terjauh berada pada bulan ke 21 . Artinya kenaikan harga minyak dunia berdampak negatif bagi pertumbuhan produksi industri. Kondisi ini dapat dipahami karena biaya yang dikeluarkan oleh sebagian besar industri dalam berproduksi makin meningkat sehingga menurunkan tingkat pertumbuhannya. Temuan ini memperkuat studi yang telah dilakukan oleh Alom, et al. (2013) terhadap Korea dan Taiwan. Studi ini juga diperkuat oleh argumen Basher dan Sadorsky (2006) bahwa peningkatan harga minyak meningkatkan biaya produksi di negara importir minyak karena tidak adanya input substitusi dari minyak mentah. Sementara Indonesia telah menjadi negara net importir minyak. 
Sebaliknya, respon inflasi domestik terhadap inovasi harga minyak dunia mengalami peningkatan. Inovasi harga minyak dunia direspon secara positif oleh kenaikan tingkat harga (inflasi) domestik dari awal periode. Respon ini makin divergence setelah bulan ke 12. Kondisi ini memperlihatkan dampak permanen dari kenaikan harga minyak dunia terhadap inflasi. Kenaikan inflasi sebagai respon dari goncangan harga minyak dunia dipengaruhi pula oleh respons penurunan produksi industri yang menyebabkan kelangkaan produksi. Secara bersamaan goncangan harga minyak dunia dan penurunan pertumbuhan produksi industri mendorong terjadinya inflasi. Temuan yang sama juga telah diungkapkan oleh Alom, et al. (2013) pada kasus Korea dan Taiwan.

Pada saat yang sama, respon tingkat bunga domestik terhadap goncangan harga minyak dunia juga mengalami peningkatan. Kondisi ini terlihat jelas pada grafik accumulated response of I to shock 1. Peningkatan atau inovasi harga minyak dunia direspon oleh kenaikan tingkat bunga domestik setelah bulan ke 5. Kondisi ini makin jelas terlihat setelah bulan ke 24. Temuan ini tidak jauh berbeda dengan studi Alom, et al. (2013) untuk Korea dan Taiwan. Kejutan harga minyak dunia menyebabkan kebijakan moneter kontraktif dengan menaikkan suku bunga. Kebijakan ini juga merespon tekanan inflasi akibat dari goncangan harga minyak dunia.

Selanjutnya, goncangan harga minyak dunia membawa dampak pula terhadap nilai tukar riil (REER). Inovasi harga minyak dunia direspon secara positif oleh nilai tukar riil. Artinya kenaikan harga minyak dunia cenderung direspon oleh kenaikan kurs rupiah terhadap dollar ${ }^{5}$. Peningkatan kurs rupiah terhadap dollar mengimplikasikan terdepresiasinya mata uang rupiah dan apresiasi dollar. Kondisi ini terjadi karena Indonesia sebagai negara importir minyak harus mengeluarkan Dollar dalam jumlah yang lebih besar. Dampak selanjutnya dari terdepresiasi nilai tukar akan menyebabkan ekspektasi inflasi meningkat dan tingkat harga akan meningkat pula dalam jangka panjang (Mishkin 2001).

\footnotetext{
${ }^{5}$ Temuan ini berkebalikan dengan studi Alom, et.al. (2013).
} 
Gambar 3 Respon Variabel Makroekonomi terhadap Goncangan Harga Minyak Dunia

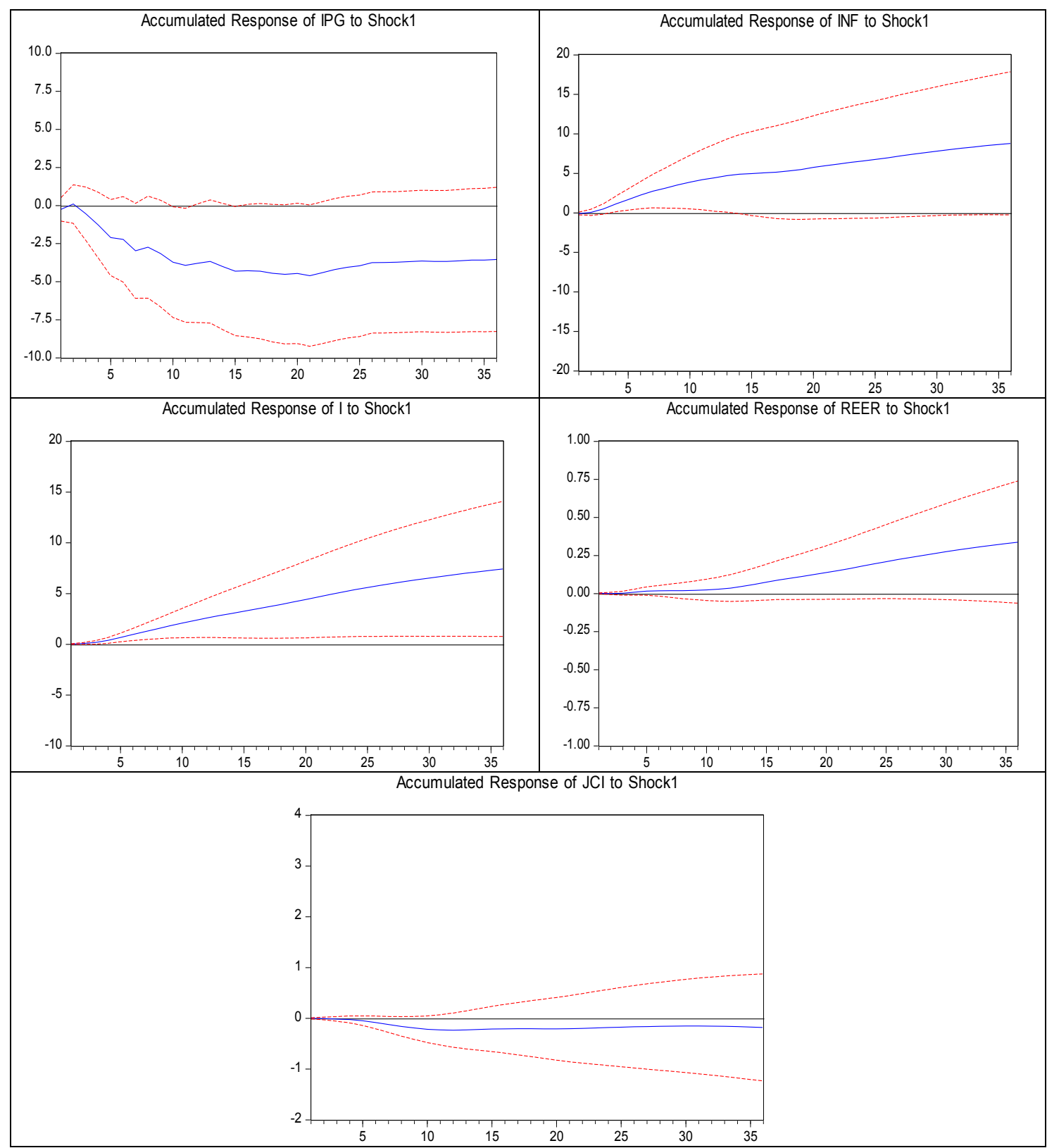

Sumber: Hasil Olahan, 2014

Shock 1 = Goncangan ROP

Temuan penelitian juga titik terjauh pada bulan ke 11 dan memperlihatkan inovasi harga minyak kembali menuju titik kesimbangan dunia mempengaruhi harga aset (harga tetapi tidak sampai pada titik saham). Secara akumulatif, inovasi keseimbangan. Artinya goncangan harga minyak dunia direspon negatif oleh harga aset. Kondisi ini terlihat jelas mulai bulan ketiga dan menemui harga minyak dunia meninggalkan dampak permanen pada harga aset. Kondisi ini dapat dipahami karena 
goncangan harga minyak mentah bagi Indonesia sebagai negara importir minyak telah membuat nilai tukar terdepresiasi. Ini tentunya juga berpengaruh pada kegiatan ekonomi yang menyebabkan inflasi mengalami peningkatan. Untuk membendung tekanan inflasi, Bank Indonesia meresponnya dengan mengawasi jumlah uang beredar melalui instrumen suku bunga (kebijakan moneter kontraktif). Kebijakan moneter kontraktif diterapkan melalui kenaikan suku bunga nominal. Kenaikan suku bunga membuat instrumen obligasi menjadi lebih menarik dibandingkan dengan saham sehingga harga saham sebagai proksi harga aset mengalami penurunan. Pada posisi itu, saham tidak menjadi pilihan investasi. Fakta ini memperjelas bahwa response harga aset terhadap goncangan harga minyak dunia bersifat negatif dan divergence.

Dari temuan empiris dan analisis impuls respon goncangan harga minyak dunia terhadap variabel makro ekonomi Indonesia telah terungkap bahwa respon semua variabel makro ekonomi yang diteliti terhadap goncangan harga minyak dunia menunjukkan pergerakan yang semakin menjauh dari titik keseimbangan (divergence). Ini berarti akumulasi respons masing-masing variabel makro ekonomi Indonesia akibat goncangan harga minyak dunia makin lama makin menguat dan memberikan pengaruh yang permanen.

\section{Impulse Response Functions}

\section{Goncangan Harga Pangan Dunia}

Pembahasan IRFs pada bagian ini memfokuskan pada pelacakan dampak kejutan harga pangan dunia (WPI) terhadap variabel-variabel makro ekonomi Indonesia seperti pertumbuhan produksi industri (IPG), tingkat bunga domestik (I), inflasi (INF), nilai tukar riil (REER), dan harga aset (JCI) merespon kejutan harga minyak (ROP). Analisis IRF goncangan harga pangan dunia melihat perubahan variabel kejutan harga minyak dunia sebesar satu standar deviasi pada awal periode yang mengakibatkan perubahan variabel makro ekonomi lainnya dalam bulanan selama jangka waktu 3 tahun. Alasan pemilihan jangka waktu 3 tahun disini juga disebabkan relatif cocok untuk mengamati perubahan harga pangan dunia terhadap variabel makro ekonomi domestik jangka pendek dan jangka panjang.

Temuan penelitian impulse response menyatakan dampak 
goncangan harga pangan dunia terhadap variabel-variabel makro ekonomi Indonesia selama 36 bulan atau 3 tahun. Kejutan harga pangan dunia segera direspon oleh pertumbuhan produksi industri dengan respon yang negatif. Pada bulan ke 9 perubahan harga pangan dunia direspon positif oleh pertumbuhan produksi industri dan kembali berbalik arah menjadi negatif setelah bulan ke 11. Selanjutnya secara berangsurangsur menuju titik keseimbangan (convergence) pada bulan ke 29. Ini berarti respon pertumbuhan produksi industri membutuhkan waktu yang relatif lama untuk menyesuaikan dengan goncangan harga pangan dunia sebelum menuju keseimbangan. Kemampuan produksi industri menyesuaikan diri terhadap dampak harga pangan dunia diduga karena umumnya industri yang menjadi variabel pada penelitian ini adalah industri manufaktur yang tidak secara langsung memanfaatkan komoditas pangan sebagai input dalam berproduksi. Kenaikan harga pangan dunia lebih berpengaruh pada industri yang memanfaatkan komoditas pangan dunia sebagai bahan baku dalam berproduksi seperti industri makanan dan minuman. Integrasi industri pangan Indonesia terhadap pasar komoditas dunia justru terlihat pada komoditas gula, minyak goreng, kacang kedelai dan jagung ${ }^{6}$. Pada industri seperti inilah yang terpengaruhi oleh goncangan harga pangan terutama beberapa komoditi telah digunakan menjadi bahan bakar (bio-fuels). 
Gambar 4 Respon Variabel Makroekonomi terhadap Goncangan Harga Pangan Dunia

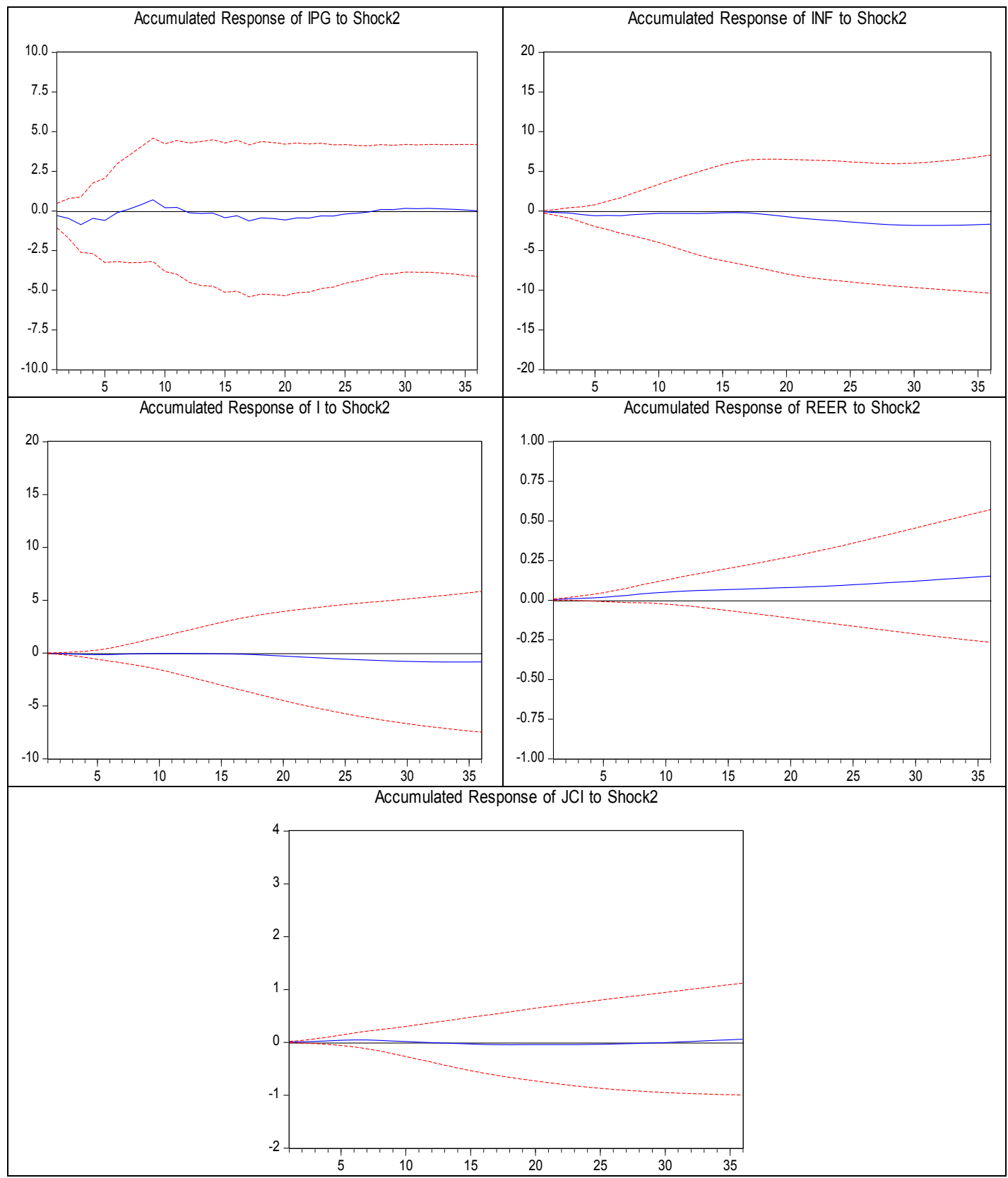

Sumber: Hasil Olahan, 2014

Shock 2 = Goncangan WPI

Selanjutnya, penelitian juga melacak akumulasi respon tingkat inflasi terhadap inovasi harga pangan dunia. Goncangan harga pangan dunia direspon tidak segera mendorong inflasi di Indonesia.
Namun, secara mengejutkan penelitian menemukan respon negatif inflasi terhadap kejutan harga pangan dunia. Fakta ini berlawanan dengan teori dimana goncangan harga pangan dunia semestinya mendorong 
kenaikan inflasi di Indonesia karena sebagian komoditas pangannya masih diimpor. Kondisi ini dapat diduga meskipun pemenuhan kebutuhan sebagian pangan diimpor dari luar negeri, goncangan harga pangan telah mengalami penyesuaian-penyusuaian dengan substitusi komoditas pangan yang diproduksi didalam negeri. Dengan kata lain, pangan dunia bukanlah merupakan leading sektor dalam inflasi. Temuan ini didukung oleh temuan Alom, et al. (2013) untuk negara Korea, Taiwan, Thailand dan Hongkong tetapi berkebalikan dengan temuan untuk negara Australia, Singapura dan India.

Disamping temuan diatas, penelitian mencoba menelusuri dampak kejutan harga pangan dunia terhadap tingkat bunga domestik. Penelitian menemukan bahwa goncangan harga pangan dunia tidak direspon segera oleh tingkat bunga domestik bahkan akumulasi respon tingkat bunga domestik terhadap inovasi harga pangan dunia cenderung convergence hingga bulan ke 17. Respon negatif tingkat suku bunga terhadap inovasi harga minyak mulai tampak pada bulan ke 20 .
Kondisi ini kemungkinan disebabkan oleh kebijakan moneter yang ekspansif melalui penurunan tingkat suku bunga domestik. Penurunan tingkat bunga domestik sebagai respon terhadap harga pangan dunia ditujukan untuk mendorong bergeraknya sektor riil yang terkait dengan produksi komoditas pangan strategis. Penurunan suku bunga ditujukan untuk menggairahkan investasi di sektor produksi tanaman pangan dalam rangka mengurangi ketergantungan pada produk impor. Walaupun terjadi penurunan suku bunga sektor pertanian, suku bunga masih relatif tinggi.

Berikutnya, hasil temuan empiris melihat dampak kejutan harga pangan dunia terhadap nilai tukar riil efektif. Goncangan harga pangan dunia pada awalnya tidak direspon oleh nilai tukar riil efektif, tetapi respon mulai terlihat setelah bulan ke 3 bahkan akumulasi respon nilai tukar riil efektif terhadap inovasi harga pangan dunia cenderung divergence sampai akhir periode (bulan ke 36). Goncangan harga pangan dunia direspon secara positif oleh nilai tukar efektif. Kejadian inovasi harga pangan dunia 
mendorong depresiasi mata uang rupiah. Kenaikan harga pangan dunia menciptakan permintaan mata uang asing mengalami peningkatan untuk pembiayaan impor bahan pangan. Kenaikan permintaan mata uang asing menyebabkan nilai mata uang rupiah menjadi melemah atau terdepresiasi. Fakta memperlihatkan bahwa goncangan harga pangan dunia memberikan dampak permanen pada terdepresiasinya mata uang rupiah yang ditunjukkan oleh nilai tukar riil efektif menjauhi titik keseimbangan.

Terakhir, penelitian melacak dampak goncangan satu standar deviasi harga pangan dunia terhadap harga aset (harga saham). Efek goncangan harga pangan dunia tidak begitu direspon oleh harga aset di pasar keuangan. Fakta ini ditunjukkan oleh respon harga aset yang selalu mendekati titik keseimbangan (convergence) selama periode simulasi. Artinya goncangan harga pangan dunia tidak memiliki dampak yang membekas terhadap harga aset. Terjadinya kejutan harga pangan dunia selalu bisa disesuaikan (direspon) oleh harga aset, namun dampaknya tidak lagi bersifat permanen dan selalu bergerak menuju titik konvergensi. Kondisi ini dapat dipahami karena sebagian besar harga aset di pasar keuangan merupakan aset industri yang tingkat integrasinya pada pasar pangan dunia relatif tidak kuat. Sebagian besar produk yang dihasilkan oleh industri di pasar keuangan adalah bukan komoditas pangan sehingga goncangan harga pangan tidak terlalu berpengaruh pada harga aset.

\section{Analisis Forecast Error Variance Decompositions (FEVDs)}

Analisis Forecast Error Variance Decompositions (FEVDs) bertujuan memprediksi kontribusi persentase varian suatu variabel dalam sistem VAR/VECM/SVAR karena adanya goncangan (Enders, 2010).Ini berarti FEVDs menginformasikan seberapa penting perubahan pergerakan setiap inovasi suatu variabel tertentu terhadap variabel endogen. Dengan menganalisis FEVDs maka akan diketahui variabel mana yang dampak goncangannya berperan penting dalam menjelaskan perubahan sebuah variabel. Karena yang menjadi titik fokus penelitian ini adalah melacak dampak 
goncangan harga minyak dan harga pangan dunia terhadap variabel makro ekonomi Indonesia, maka FEVDs membahas kontribusi goncangan harga minyak dan harga pangan terhadap variabel makro ekonomi yang menjadi objek penelitian. Oleh karena itu, analisis tidak membahas varian decompositions dari harga minyak dan harga pangan dunia, tetapi lebih mengutamakan menganalisis varian decompositions dari pertumbuhan produksi industri, inflasi, tingkat bunga domestik, nilai tukar riil dan harga aset. Dengan demikian, variabel harga minyak dan harga pangan dunia diperlakukan sebagai variabel eksogen. Simulasi FEVDs ini diproyeksikan selama 36 bulan agar dapat dianalisis efek jangka panjangnya.

Temuan penelitian memperlihatkan komposisi varian pertumbuhan produksi industri akibat adanya goncangan variabel lainnya. Goncangan harga minyak dunia memiliki kontribusi yang relatif besar terhadap perubahan pertumbuhan produksi industri yaitu sebesar 4,62 persen pada bulan 1 dan pengaruhnya semakin besar hingga bulan 36 yaitu sebesar 7,03 persen. Guncangan harga minyak dapat mendorong naiknya biaya marjinal

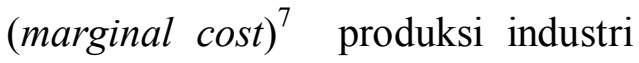
karena kenaikan harga memberikan sinyal berkurangnya ketersediaan input dasar untuk produksi sehingga mengurangi produksi (Brown and Yücel, 2002; Lardic and Mignon, 2006, 2008; dan Dogrul and Soytas, 2010).

Walaupun kontribusi goncangan harga pangan dunia tidak sebesar kejutan harga minyak dunia, gocangan harga pangan tetap memberikan kontribusi dalam perubahan pergerakan pertumbuhan produksi industri di Indonesia. Kontribusi harga pangan dunia terhadap komposisi varian pertumbuhan produksi industri mengalami perubahan dengan pengaruhnya makin membesar tetapi pergerakannya relatif lambat yang ditunjukkan oleh pengaruh pada bulan pertama sebesar 0,41 persen dan pada bulan ke 36 kontribusinya

\footnotetext{
${ }^{7}$ Sementara dampak kenaikan BBM terhadap biaya produksi sebesar 1,2 persen. Dapat dilihat

dihttp://bisniskeuangan.kompas.com/read/ 2013/06/22/1604266/Harga.BBM.Naik.Ong kos.Produksi.Naik.1.2.Persen diakses 4 Januari 2014.
} 
menjadi sebesar 3,25 persen.

Penelitian juga menemukan bahwa variabel yang berkontribusi besar dalam komposisi varian pertumbuhan produksi industri adalah tingkat bunga selain variabel pertumbuhan produksi industri itu sendiri. Tingkat bunga pada bulan pertama belum menampakkan pengaruh yang jelas pada perubahan pergerakan pertumbuhan produksi industri, tetapi setelah bulan ke tiga kelihatan makin berperan hingga mencapai 20,57 persen pada bulan ke 36. Tingkat bunga merupakan variabel penting yang mempengaruhi pilihan investor dalam berinvestasi apakah pada obligasi atau saham.

Goncangan harga minyak menunjukkan proporsi dominan dalam fluktuasi pergerakan inflasi di Indonesia. Kontribusi goncangan harga minyak dunia dalam perubahan pergerakan inflasi memang belum terlihat pada bulan pertama, tetapi pada bulan ke tiga makin memperlihatkan kontribusinya dan bersifta permanen. Fakta ini dibuktikan dengan peningkatan kontribusi terhadap pergerakan inflasi dari 0,63 persen pada bulan pertama menjadi 19,35 persen di bulan ke $36^{8}$. Fakta ini mempertegas rentannya pergerakan inflasi di Indonesia terhadap harga minyak dunia. Sedangkan pengaruh goncangan harga pangan dunia terhadap perubahan pergerakan inflasi di Indonesia relatif rendah antara $0,73-2,28$ persen. Selain itu, harga aset juga relatif dominan dalam membentuk perubahan pergerakan inflasi dengan kontribusi berfluktuasi. Pada bulan pertama kontribusi harga aset dalam pergerakan inflasi belum terlihat, baru pada bulan ketiga menyatakan kontribusi yang jelas berkisar antara 4,77 hingga 6,48 persen.

\footnotetext{
${ }^{8}$ Perubahan harga BBM selama periode penelitian mencatat pada era Megawati Soekarnoputri:2001: Rp 1.150 naik ke Rp 1.450 dan 2002: Rp 1.450 naik jadi Rp 1.550. Pada masa pemerintahan Susilo Bambang Yudhoyono :2004: Rp 1.500 naik jadi Rp 1.810; 2005: Rp 1.810 naik jadi Rp 2.400; 2005: Rp 2.400 naik jadi Rp 4.500; 2008: Rp 4.500 naik jadi Rp 6.000; 2008: Rp 6.000 turun ke Rp 5.500; 2008: Rp 5.500 turun ke Rp 5.000; 2009: Rp 5.000 turun ke Rp 4.500; 2013: Rp.4.500 naik jadi Rp.6.500
} 
Tabel 2 Forecast Error Variance Decomposition (FEDVS)

\begin{tabular}{|c|c|c|c|c|c|c|c|c|c|}
\hline \multirow{2}{*}{$\begin{array}{c}\text { Variance } \\
\text { Decomposition } \\
\text { of }\end{array}$} & \multirow{2}{*}{$\begin{array}{c}\text { Period } \\
\text { (Monthly) }\end{array}$} & \multicolumn{8}{|c|}{ Shock } \\
\hline & & ROP & WPI & IPG & INF & IW & I & REER & JCI \\
\hline \multirow[t]{6}{*}{ IPG } & 1 & 0,296360 & 0,406601 & 99,29704 & 0,000000 & 0,000000 & 0,000000 & 0,000000 & 0,000000 \\
\hline & 3 & 2,091805 & 0,954298 & 76,89307 & 3,025362 & 1,094503 & 11,66046 & 0,751313 & 3,529185 \\
\hline & 6 & 5,364658 & 1,964196 & 64,40735 & 3,582725 & 1,897443 & 14,78036 & 0,886248 & 7,117019 \\
\hline & 12 & 6,760625 & 2,812217 & 52,65637 & 4,700059 & 2,158616 & 20,75928 & 1,213797 & 8,939029 \\
\hline & 24 & 6,988514 & 3,184858 & 50,81865 & 4,693309 & 2,301970 & 20,46650 & 1,400827 & 10,14538 \\
\hline & 36 & 6,980803 & 3,249526 & 50,30511 & 4,873552 & 2,290042 & 20,56943 & 1,676116 & 10,05542 \\
\hline \multirow[t]{6}{*}{ INF } & 1 & 0,632597 & 1,316513 & 0,088891 & 97,96200 & 0,000000 & 0,000000 & 0,000000 & 0,000000 \\
\hline & 3 & 6,363754 & 0,729829 & 0,289780 & 65,17913 & 4,606649 & 17,24779 & 0,813865 & 4,769203 \\
\hline & 6 & 18,53679 & 1,285869 & 0,194877 & 41,21173 & 3,348174 & 28,18797 & 0,749765 & 6,484818 \\
\hline & 12 & 17,61405 & 0,990141 & 1,933259 & 28,39377 & 3,925139 & 40,87091 & 0,887505 & 5,385215 \\
\hline & 24 & 18,54012 & 2,045851 & 3,855430 & 26,07795 & 4,254608 & 38,76910 & 1,559736 & 4,897205 \\
\hline & 36 & 19,34818 & 2,282580 & 4,615976 & 25,77259 & 4,304445 & 35,49635 & 2,717127 & 5,462750 \\
\hline \multirow[t]{6}{*}{ I } & 1 & 1,841661 & 0,766742 & 0,000000 & $2,18 \mathrm{E}-30$ & 0,078979 & 97,31262 & 0,000000 & 0,000000 \\
\hline & 3 & 6,289788 & 1,102009 & 1,674105 & 4,721461 & 0,478012 & 81,05276 & 0,077386 & 4,604482 \\
\hline & 6 & 23,24321 & 0,576092 & 1,660054 & 2,414623 & 2,289261 & 62,83752 & 0,069155 & 6,910084 \\
\hline & 12 & 26,23267 & 0,380223 & 1,849053 & 1,236748 & 2,123050 & 63,42059 & 0,105805 & 4,651864 \\
\hline & 24 & 31,40947 & 0,825656 & 3,555882 & 2,047040 & 1,715471 & 56,34474 & 0,350543 & 3,751201 \\
\hline & 36 & 34,61975 & 0,986056 & 3,207789 & 2,603998 & 2,014784 & 50,87189 & 1,334773 & 4,360964 \\
\hline \multirow[t]{6}{*}{ REER } & 1 & 0,488153 & 4,172876 & 2,541247 & 8,105860 & 1,211045 & 0,324302 & 83,15652 & 0,000000 \\
\hline & 3 & 0,260901 & 3,262149 & 3,668360 & 10,74422 & 9,572948 & 10,66380 & 50,51433 & 11,31330 \\
\hline & 6 & 3,980684 & 4,284310 & 6,873429 & 12,27049 & 8,283808 & 14,34629 & 37,66561 & 12,29538 \\
\hline & 12 & 3,868176 & 6,513894 & 14,40816 & 6,933101 & 5,836341 & 17,85129 & 35,57224 & 9,016796 \\
\hline & 24 & 18,31168 & 3,366451 & 9,589093 & 3,069445 & 8,242640 & 29,06529 & 23,94198 & 4,413412 \\
\hline & 36 & 20,84129 & 3,684841 & 7,077484 & 2,042243 & 13,37276 & 29,31250 & 20,74314 & 2,925747 \\
\hline
\end{tabular}




\begin{tabular}{|l|l|l|l|l|l|l|l|l|l|}
$\mathrm{JCI}$ & 1 & 0,006643 & 0,949313 & 3,265567 & 1,172494 & 3,792967 & 0,004678 & 6,353375 & 84,45496 \\
& 3 & 0,950855 & 1,290084 & 7,627165 & 2,437709 & 1,683802 & 0,365157 & 1,984872 & 83,66036 \\
& 6 & 6,160794 & 1,190057 & 12,02173 & 2,370090 & 0,970237 & 1,879546 & 1,058018 & 74,34953 \\
& 12 & 9,256590 & 1,196922 & 16,51887 & 8,469162 & 1,491391 & 5,769895 & 1,859638 & 55,43753 \\
& 24 & 6,509775 & 1,123838 & 21,19449 & 8,250841 & 2,239510 & 6,254946 & 3,339537 & 51,08707 \\
& 36 & 6,041553 & 1,727357 & 21,32789 & 7,519705 & 4,249778 & 5,906327 & 4,724211 & 48,50318 \\
& & & & & & & &
\end{tabular}

Sumber: Hasil Olahan, 2014

Sementara itu, variabel makro ekonomi lainnya yang berkontribusi penting terhadap perubahan pergerakan inflasi adalah goncangan tingkat bunga. Pengaruh tingkat bunga belum terlihat nyata di bulan pertama, namun berangsur-angsur mendominasi komposisi perubahan pergerakan inflasi hingga mencapai puncaknya pada bulan ke 12 sebesar 40,87 persen. Bagi Bank Sentral, Bank Indonesia, tingkat bunga merupakan instrumen penting dalam mengendalikan pergerakan inflasi. Pada saat inflasi tinggi, biasanya Bank Indonesia mengeluarkan kebijakan moneter kontraktif yang tercermin dari tingkat suku bunga tinggi untuk mengurangi jumlah uang beredar. Sebaliknya, pada saat terjadi deflasi Bank Indonesia mendorong peningkatan kegiatan ekonomi dengan kebijakan moneter ekspansif melalui penurunan tingkat bunga sehingga mendorong investasi. Studi yang dilakukan oleh Erawati dan
Llewelyn (2002) menyatakan bahwa Bank Indonesia sering mengeluarkan kebijakan uang ketat (tight money policy) dengan menaikkan tingkat bunga dalam mengatasi inflasi yang terjadi.

Lebih lanjut, penelitian menyelidiki kontribusi harga minyak dan harga pangan dunia terhadap perubahan pergerakan tingkat bunga. Secara nyata terlihat bahwa goncangan harga minyak dunia memiliki kontribusi yang dominan dalam perubahan pergerakan tingkat bunga. Kontribusi harga minyak dunia terhadap perubahan pergerakan tingkat bunga telah tampak mulai pada bulan pertama hingga bulan ke 36 . Kontribusi goncangan harga pangan dunia meningkat tajam pada bulan ke 6 sebesar 23,24 persen dan kontribusinya kian membesar hingga pada bulan ke 36 sebesar 34,62 persen. Berbeda dengan peranan goncangan harga minyak dunia, kejutan harga pangan 
dunia berkontribusi terhadap perubahan pergerakan tingkat dalam persentase yang relatif rendah dan cenderung mengalami perlambatan. Kontribusi harga pangan dunia terhadap komposisi varian tingkat bunga berkisar antara 0,38 persen hingga 1,1 persen. Kontribusi terbesar terjadi pada bulan ke 6. Fakta ini juga mengimplikasikan bahwa harga pangan dunia belum menjadi fokus utama dalam perubahan pergerakan tingkat bunga. Sebaliknya, perubahan pergerakan tingkat bunga dominan dipengaruhi oleh kontribusi harga minyak dunia. Faktanya, harga minyak dunia telah memberikan pengaruh yang besar pada pergerakan inflasi. Untuk mengendalikan inflasi Bank Indonesia cenderung mempraktekkan kebijakan moneter kontraktif melalui instrumen suku bunga.

Hasil pelacakan berikutnya adalah variance decomposition dari nilai tukar riil efektif. Variabilitas nilai tukar riil efektif dipengaruhi oleh tingkat bunga, harga minyak dunia dan nilai tukar riil efektif itu sendiri. Kemampuan harga minyak dunia mempengaruhi pergerakan nilai tukar riil semakin lama makin membesar. Pengaruh terakhir pada bulan ke 36 sebesar 20,84 persen. Dampak harga pangan dunia terhadap variabilitas nilai tukar riil efektif berfluktuasi yang berkisar antara 3,26 persen hingga 6,51 persen. Pengaruh yang paling dominan terhadap perubahan pergerakan nilai tukar riil efektif adalah goncangan tingkat bunga domestik. Walaupun pada bulan pertama kontribusi tingkat bunga dalam komposisi varian nilai tukar riil efektif hanya sebesar 0,32 persen, pengaruh tingkat bunga makin menguat mulai pada bulan ke tiga dan mencapai dominasi tertinggi sebesar 29,31 di akhir periode yaitu bulan ke 36. Sementara itu, kontribusi inflasi terhadap nilai tukar efektif memperlihatkan makin lama makin berkurang. Pada bulan pertama kontribusi inflasi dalam pergerakan nilai tukar riil efektif masih sebesar 8,11 persen, tetapi pada akhir periode menjadi sebesar 2,04 persen saja.

Pada bagian akhir penelusuran variance decomposition adalah tentang harga saham yang merupakan proksi untuk harga aset. Selain harga aset itu sendiri, variabilitas harga aset dominan dipengaruhi oleh pertumbuhan produksi industri, inflasi, dan harga minyak dunia. Pengaruh harga minyak dunia dalam komposisi harga aset pada awal periode belum direspon, pengaruh mulai tampak pada bulan ke 6 hingga 
akhir periode (bulan ke 36) sebesar 6,04 persen. Pengaruh harga minyak dunia dalam perubahan pergerakan harga aset mencapai titik puncak pada bulan ke 12. Sementara itu, pengaruh harga pangan dunia dalam komposisi variabilitas harga aset masih relatif rendah, yakni berkisar antara 0,95 persen sampai dengan 1,73 persen. Pengaruh harga pangan dunia berangsur-angsur membesar, tetapi tidak terlalu cepat yang ditunjukkan oleh kontribusinya sebesar 1,73 persen. Fakta ini berarti pengaruh harga pangan dunia tidak secara langsung mempengaruhi variabilitas harga aset.

Pengaruh yang dominan terhadap variablitas harga aset adalah pertumbuhan produksi industri dan inflasi selain harga aset itu sendiri. Pengaruh pertumbuhan produksi industri dalam perubahan pergerakan harga aset segera direspon pada bulan pertama sebesar 3,27 persen. Pengaruh ini makin membesar dan pada bula ke 36 mencapai 21,33 persen. Penerimaan industri sangat tergantung dari pertumbuhan produksinya, pertumbuhan produksi yang tinggi dapat meningkatkan arus kas industri sehingga menaikkan harga asetnya. Sedangkan, pengaruh inflasi dalam variabilitas harga aset berkisar antara
1,17 persen hingga 8,47 persen. Tekanan inflasi mempengaruhi harga aset karena pada saat terjadinya inflasi, biaya produksi mengalami peningkatan dan harga jual pun meningkat. Peningkatan harga jual berimbas pada berkurangnya daya beli konsumen terhadap output industri. Penurunan output berarti menurunkan arus kas dan berujung pada penurunan harga aset dan saat bersamaan investor cenderung membeli instrumen obligasi dibandingkan dengan membeli saham industri sebagai upaya mengantsipasi fluktuasi harga saham. Kondisi ini menyebabkan harga aset mengalami penurunan

\section{Analisis Ekonomi Model SVAR}

Penggunaan analisis Structural Vector AutoRegressive (SVAR) pada dampak goncangan harga minyak dan pangan dunia terhadap perekonomian makro Indonesia didasarkan pada upaya untuk menemukan suatu solusi yang masuk akal. Untuk itu, dalam analisis SVAR dilakukan pembebanan dari satu set restriksi (pembatasan). Pembatasan ini berguna untuk menguji model ketika suatu struktur overidentified $^{9}$ ingin diperoleh. Dalam posisinya, SVAR merupakan jembatan

${ }^{9}$ Kondisi dimana lebih banyak koefisien reduced form dibandingkan dengan parameter struktural 
antara teori ekonomi dan multiple time series analysis. Konsekuensinya metode SVAR berguna menganalisis dampak ekonomi ketika ada suatu inovasi dan respon terhadap adanyainovasi.

Inovasi harga minyak dan pangan dunia memberikan dampak yang beragam terhadap perekonomian makro Indonesia. Dampak goncangan harga minyak terhadap perekonomian Indonesia sebagai negara net importir ${ }^{10}$ minyak direspon dengan menurunnya pertumbuhan produksi industri, peningkatan inflasi dan kebijakan moneter kontraktif, depresiasi nilai tukar hingga berujung pada menurunnya harga aset di pasar keuangan. Fakta rentannya perekonomian makro Indonesia terhadap inovasi harga minyak dunia terlihat dari besarnya kontribusi variabel harga minyak dunia dalam mempengaruhi variabilitas variabel makro ekonomi Indonesia yang diteliti. Secara garis besar, kondisi-kondisi ini telah sesuai dengan teori ekonomi yang berkembang.

\footnotetext{
10 Pada bulan Mei 2008, Indonesia secara resm mengajukan surat untuk keluar dari OPEC setelah menjadi anggota semenjak Desember 1962. Kondisi ini disebabkan Indonesia tidak mampu memenuhi kuota produksi yang telah ditetapkan OPEc karena sejak 2003 Indonesia telah menjadi importir minyak.Efektif pada Januari 2009 Indonesia tidak lagi menjadi anggota OPEC.
}

Sebagai negara importir minyak, Indonesia menjadi rentan terhadap goncangan harga minyak dunia. Inovasi harga minyak dunia direspon oleh penurunan pertumbuhan produksi Industri. Goncangan harga minyak sebagai input dalam berproduksi dari sebuah industri ${ }^{11}$ manufaktur telah meningkatkan biaya produksi. Peningkatan biaya produksi mendorong penurunan pertumbuhan produksi industri. Temuan yang sama diperlihatkan oleh Kumar (2009) yang menganalisis makro ekonomi India. Penurunan pertumbuhan produksi industri memicu kenaikan harga produk (cost push inflation) bersamaan dengan kenaikan inflasi akibat dari inovasi harga minyak dunia. Sebagai upaya meredam inflasi sebagai akibat dari kejutan harga minyak dunia bank sentral mengeluarkan kebijakan uang ketat (tight money policy) yang terlihat dari peningkatan suku bunga domestik (BI-rate).

\footnotetext{
${ }^{11}$ Industri menggunakan BBM non subsidi
} 
Kebijakan ini dapat pula meningkat, nilai tukar riil efektif yang membantu meredam rupiah yang semakin terdepresiasi pada masa goncangan harga minyak. Tetapi semua kondisi ini telah mendorong makin memperburuk harga aset di terdepresiasi dan tingkat bunga yang meningkat membuat investor memilih untuk berinvestasi di instrumen obligasi dibandingkan dengan membeli pasar keuangan. Pertumbuhan produksi industri kian menurun, inflasi

Tabel 3 Ringkasan Hasil Penelitian

\begin{tabular}{|l|l|l|l|l|}
\hline Inovasi & $\begin{array}{l}\text { Variabel } \\
\text { respons }\end{array}$ & \multicolumn{1}{|c|}{ IRFs } & \multicolumn{1}{|c|}{ FEVDs } & \multicolumn{1}{|c|}{ Keterangan } \\
\hline \multirow{4}{*}{ ROP } & IPG & Negatif & Besar & Sesuai teori \\
\cline { 2 - 5 } & INF & Positif & Besar & Sesuai teori \\
\cline { 2 - 5 } & I & Positif & Besar & Sesuai teori \\
\cline { 2 - 5 } & REER & Depresiasi & Besar & Sesuai teori \\
\cline { 2 - 5 } & JCI & Negatif & Besar & Sesuai teori \\
\hline \multirow{4}{*}{ WPI } & IPG & $\begin{array}{l}\text { Negatif (Jangka } \\
\text { Pendek) } \\
\text { Positif (Jangka } \\
\text { Panjang) }\end{array}$ & Kecil & $\begin{array}{l}\text { Sesuai } \\
\text { (Jangka Panjang) }\end{array}$ \\
\cline { 2 - 5 } & INF & $\begin{array}{l}\text { Negatif } \\
\text { Tidak ada respon } \\
\text { (Jangka Pendek) } \\
\text { Negatif (Jangka } \\
\text { Panjang) }\end{array}$ & Sangat Kecil & Tidak sesuai teori \\
\cline { 2 - 5 } & I & Depresiasi & Besar & Sesuai teori \\
\cline { 2 - 5 } & REER & Positif & Kecil & Tidak sesuai teori \\
\cline { 2 - 5 } & JCI & \multicolumn{2}{|l}{} \\
\hline
\end{tabular}

Sumber: Hasil Olahan, 2014

Sementara itu, Indonesia sebagai negara yang masih bertumpu pada sektor pertanian memperlihatkan dampak goncangan harga pangan dunia direspon negatif oleh pertumbuhan produksi industri pada jangka pendek dan positif dalam jangka panjang. Respon jangka panjang sesuai dengan teori ekonomi dimana kenaikan harga pangan dunia mendorong pertumbuhan produksi industri yang bergerak pada pengolahan hasil produksi komoditas pangan. Tetapi besaran dampak kenaikan harga pangan dunia terhadap pertumbuhan produksi Industri relatif kecil. Temuan yang mengejutkan adalah dampak negatif goncangan 
harga pangan terhadap inflasi. Fakta ini menjadi sebuah teka teki harga (prize puzzle). Seharusnya kenaikan harga pangan dunia akan mendorong kenaikan inflasi. Tetapi hasil temuan empiris justru memperlihatkan kondisi yang berkebalikan. Fakta ini diduga karena Indonesia bukanlah negara net importir pangan sebab di negara net importir pangan goncangan harga pangan menaikkan inflasi seperti studi von Braum (2008). Kondisi ini tentu saja diikuti oleh kebijakan moneter ekspansif Bank Sentral melalui media penurunan tingkat suku bunga domestik sebagai upaya menggerakkan perekonomian.

Selanjutnya, kejutan harga pangan dunia direspon oleh melemahnya rupiah terhadap dollar (depresiasi). Temuan ini memiliki kesamaan dengan dampak goncangan harga minyak dunia. Sebagai akibat dari kenaikan harga pangan dunia maka kebutuhan mata uang asing (dollar) meningkat untuk keperluan impor pangan. Kondisi ini pada bersamaan telah melemahkan rupiah. Kondisi ini seharusnya direspon dengan peningkatan suku bunga sebagai upaya meredam depresiasi rupiah, tetapi faktanya bank sentral pada saat bersamaan tetap mempertahankan suku bunga yang rendah sebagai respon dari penurunan inflasi yang bersumber dari komoditas pangan. Kebijakan ini berkebalikan dengan respon bank sentral terhadap dampak kenaikan harga minyak dunia karena pemerintah juga merespon goncangan harga minyak dunia dengan berulang kali menaikkan harga bahan bakar minyak.

Selain temuan di atas, penelitian juga mengemukakan respon positif harga aset terhadap kenaikan harga pangan dunia. Tetapi besaran kontribusi kenaikan harga pangan relatif sangat kecil. Respon positif harga aset terhadap goncangan harga pangan dunia diduga hanya dinikmati oleh sebagian kecil industri yang memiliki bisnis inti pada produk pangan dan pengolahan pangan yang bersumber di dalam negeri. Namun aset yang diperdagangkan di pasar keuangan relatif sedikit yang bergerak pada komoditas pangan dibandingkan dengan manufaktur sehingga respon aset secara keseluruhan menjadi relatif kecil. Dalam jangka panjang, goncangan harga pangan dunia tidak direspon oleh harga aset dan cenderung persistent (tetap) pergerakannya sampai dengan akhir periode. 
PENUTUP

Penelitian

ini

telah

menginvestigasi dampak goncangan harga minyak dan harga pangan dunia terhadap perekonomian makro Indonesia menggunakan pendekatan Structural Vector Autoregressive (SVAR) yang memanfaatkan data bulanan sepanjang periode 2001M01 sampai dengan 2013M08. Pendekatan SVAR memperlihatkan analisis impulse response functions (IRFs) dan forecast error variance decompositions (FEVDs) dari pertumbuhan produksi industri, inflasi, nilai tukar riil efektif, tingkat bunga domestik, dan harga aset terhadap inovasi harga minyak dan harga pangan dunia. Untuk memperkuat temuan IRFs dan FEVDs dilakukan pula analisis pass-through effect dari goncangan harga minyak dan pangan dunia.

Sebagai negara net importir minyak, inovasi harga minyak dan pangan dunia memberikan dampak yang beragam terhadap perekonomian makro Indonesia. Dampak goncangan harga minyak direspon dengan menurunnya pertumbuhan produksi industri, peningkatan inflasi dan kebijakan moneter kontraktif, depresiasi nilai tukar hingga berujung pada menurunnya harga aset di pasar keuangan. Fakta ini mengimplikasikan rentannya perekonomian makro Indonesia terhadap goncangan harga minyak dunia yang terbukti dari besarnya peranan variabel harga minyak dunia dalam variabilitas makro ekonomi Indonesia. Secara umum, temuan-temuan ini telah sesuai dengan teori ekonomi yang berkembang.

Goncangan harga minyak telah berdampak pada kenaikan harga input sehingga meningkatkan biaya produksi dari industri manufaktur. Peningkatan biaya produksi mendorong penurunan pertumbuhan produksi industri. Kondisi ini memicu kenaikan harga jual produk industri yang bersamaan dengan kenaikan inflasi sebagai akibat dari inovasi harga minyak dunia. Untuk mengendalikan inflasi, bank sentral mengeluarkan kebijakan monter kontraktif berupa peningkatan suku bunga domestik (BI-rate). Kebijakan ini dapat pula ditujukan pula untuk meredam rupiah yang kian terdepresiasi pada masa goncangan harga minyak. Faktanya, kondisi ini telah memperburuk harga aset di pasar keuangan. Akibatnya, pertumbuhan produksi industri makin menurun, inflasi kian meningkat, nilai tukar riil efektif terus terdepresiasi dan tingkat bunga yang meningkat membuat 
investor memilih untuk berinvestasi di instrumen obligasi dibandingkan dengan membeli aset. Temuan goncangan harga minyak terhadap perekonomian makro Indonesia cenderung persistent dalam jangka panjang.

Sementara itu, Indonesia sebagai negara yang masih bertumpu pada sektor pertanian memperlihatkan dampak goncangan harga pangan dunia direspon negatif oleh pertumbuhan produksi industri pada jangka pendek dan positif dalam jangka panjang. Temuan di luar perkiraan adalah dampak negatif goncangan harga pangan terhadap inflasi menjadi sebuah teka teki harga (prize puzzle). Sesuai teori kenaikan harga pangan dunia akan mendorong kenaikan inflasi, faktanya justru memperlihatkan kondisi yang berkebalikan. Fakta ini diduga karena Indonesia bukanlah negara net importir pangan. Kondisi ini diikuti oleh kebijakan moneter ekspansif Bank Sentral terlihat dari penurunan tingkat suku bunga domestik. Tetapi saat bersamaan kejutan harga pangan dunia direspon oleh melemahnya rupiah terhadap dollar (depresiasi). Kondisi ini seharusnya direspon dengan peningkatan suku bunga sebagai upaya meredam depresiasi rupiah, tetapi faktanya bank sentral pada saat bersamaan tetap mempertahankan suku bunga yang rendah sebagai respon dari penurunan inflasi yang bersumber dari komoditas pangan. Penelitian juga menunjukkan respon positif harga aset terhadap kenaikan harga pangan dunia. Tetapi besaran kontribusi kenaikan harga pangan relatif sangat kecil. Dalam jangka panjang, goncangan harga pangan dunia tidak direspon oleh harga aset dan cenderung tetap (persistent) pergerakannya sampai dengan akhir periode simulasi.

Berpijak pada hasil temuan empiris di atas, maka ada beberapa saran dan rekomendasi yang bisa diberikan, yaitu: a) Memperkuat fundamental perekonomian makro Indonesia dengan mendesain kebijakan yang efektif dan terukur dalam mengantisipasi goncangan harga minyak dan pangan dunia; b) Mengoptimalkan pemanfaatan teknologi informasi dalam menciptakan early warning system dampak goncangan harga minyak dan pangan dunia terhadap perekonomian Indonesia; c) Mengembangkan sumber energi alternatif terbarukan (renewable energy sources) dengan harga kompetitif sebagai upaya mengurangi 
ketergantungan yang tinggi terhadap produk minyak mentah yang bersumber dari luar negeri; d) Meningkatkan cadangan pangan (food security) dan mendorong produksi pangan dalam negeri sebagai upaya mengantisipasi goncangan harga pangan dunia yang dapat berujung pada krisis pangan; e) Menyatukan pandangan berbagai pihak terkait dalam proses penyusunan kebijakan dan strategi ketahanan energi dan pangan nasional dengan melibatkan daerah-daerah sebagai ujung tombak; dan f) Meningkatkan kesadaran dan partisipasi aktif pelaku ekonomi dan masyarakat secara luas dalam mengimplimentasikan strategi ketahanan pangan dan energi nasional melalui peningkatan efisiensi konsumsi energi dan produksi pangan.
Untuk penelitian selanjutnya, beberapa saran berikut dapat menjadi pertimbangan: a) Penelitian selanjutnya penting menyertakan variabel-variabel makro ekonomi yang lebih kompleks untuk melacak lebih mendalam dan detail perilaku goncangan harga minyak dan pangan dunia terhadap perekonomian makro Indonesia; b) Penelitian berikutnya perlu menemukan model penelitian alternatif yang lebih tepat untuk menggambarkan pengaruh harga minyak dan pangan dunia terhadap perekonomian makro Indonesia; dan c) Secara spesifik kedepan perlu studi empiris yang dapat mengukur dan menjawab teka teki harga (price puzzle) dari goncangan harga pangan dunia dalam perekonomian makro Indonesia.

\section{DAFTAR PUSTAKA}

Abott, P.C., Hurt, C.,\& Tyner, W.E.(2009). What's driving food prices? Farm foundation issue report.

Adebiyi, M.A., Adenuga, A.O., Abeng, M.O.,\& Omanukwue, P.N.(2009). Oil Price Shocks, Exchange Rate and Stock Market Behaviour: Empirical Evidence from Nigeria. Research Paper, pp 1 - 41, Central Bank of Nigeria.

Aksoy, M.A. \& Ng, F. (2008). Who are the net food importing countries? : The World Bank.Policy Research Working Paper Series: 4457.

Alom, F., Ward, B.D., \& Hu, B.(2013).Macroeconomic Effects of World Oil and Food Price Shocks in Asia and Pacific Economies: Application of SVAR Models.OPEC Energy Review, 37(3), 327-372. 
Apergis, N., \& Rezitis, A. (2011). Food Price Volatility and Macroeconomic Factors: Evidence from GARCH and GARCH-X Estimates.Journal of Agricultural and Applied Economics, 43(1), 95-110.

Balke, N.S., Brown, S.P.A., \& Yücel, M.K.(2010). Oil Price Shocks and U.S. Economic Activity: An International Perspective. Discussion Paper, Resources for the Future.

Basher, S.A., \& Sadorsky, P. (2006). Oil price risk and emerging stock markets.Global Finance Journal, vol. 17(2), 224-251.

Blanchard, O.J. \& Gali, J.(2007). The macroeconomic effects of oil price shocks: Why are the 2000s so different from the 1970s? Department of Economics and Business, Universitat Pompeu Fabra, Economics Working Papers.

Brown, S.P.A.,\& Yucel, M.K.(2002). Energy prices and aggreagte economic activity: An interpretative survey.Quarterly Review of Economics and Finance, 42, 193-208.

Bruno, M.,\&Sachs, J.(1985). Economics and Worldwide Stagflation. Harvard University Press, Cambridge.

Burbidge, J.,\& Harrison, A. (1984). Testing for the effects of oil-price rises using vector autoregressions.International Economic Review, 25 (2), 459-484.

Cuňado, J.,\& Gracia, F.P.(2003). Do oil price shocks matter? Evidence for some european countries. Energy Economics, 25, 137-154.

Davis, S.J.,\& Haltiwanger, J. (2001). Sectoral job creation and destruction responses to oil price changes. Journal of Monetary Economics, 48 (3), 465-512.

Dimitrova, D. (2005). The Relationship between Exchange Rates and Stock Prices: Studied in a Multivariate Model. Issues in Political Economy, 14, 1 - 25.

Doğrul, H. G.,\& Soytas, U.(2010). Relationship between Oil Prices, Interest Rate, and Unemployment: Evidence from an Emerging Market. Energy Economics, 32, $1523-1528$.

Erawati, N., \& Llewelyn, R.(2002). Analisa Pergerakan Suku Bunga dan Laju Ekspektasi Inflasi Untuk Menentukan Kebijakan Moneter di Indonesia. Jurnal Manajemen \& Kewirausahaan, 4(2), 98 - 107.

Finn, M.G.(2000). Perfect competition and the effects of energy price increases on economic activity. Journal of Money, Credit and banking, 32 (3), 400-416.

Galesi, A.,\& Lombardi, M.J.(2009). External shocks and interantional inflation linkages: A global var analysis. European central bank, WP. 1062.

Gisser, M.,\& Goodwin, H.T.(1986). Crude oil and macroeconomy: Tests for some popular notions. Journal of Money, Credit and Banking, 18, 95-103. 
Hakro, A.N.,\& Omezzine, A.M. (2010). Macroeconomic Effects of Oil and Food Price Shocks to the Oman Economy. Middle Eastern Finance and Economics, 6, 72-90.

Hamilton, J.D.(1983). Oil and the macroeconomy since world war II. Journal of Political Economy, 91 (2), 228-248.

Hamilton, J.D.(1994). Time Series Analysis. Princeton University Press, Princeton.

Hamilton, J.D. (1996). This is what happened to the oil price-macroeconomy relationship. Journal of Monetary Economics, 38 (2), 215-220.

Hamilton, J.D.(2003). What is an oil shock? Journal of Econometrics, 113 (2), 363398.

Hamilton, J.D. (2009). Understanding Crude Oil Prices. Energy Journal, 30(2): 179206.

Headey, D.,\& Fan, S. (2008). Anatomy of a Crisis: The Causes and Consequences of Surging Food Prices. Agricultural Economics, 39, 375-391.

Jones, D.W., Leiby, P. N.,\&Paik,I. K. (2004). Oil Price Shocks and the Macroeconomy: what HasBeen Learned Since 1996? The Energy Journal, 25, $1-32$.

Keane, M.P.,\& Prasad, E.S.(1996). The employment and wage effects of oil price chnages: A sectoral analysis. Review of Economics and Statistics, 78 (3), 389400 .

Kim, S., \& Roubini,N. (1999). Exchange Rate Anomalies in the Industrial Countries: A Solution with a Structural VAR Approach. Journal of Monetary Economics, 45, 561-586.

Kumar, S.(2009). The Macroeconomic Effects of Oil Price Shocks: Empirical Evidence for India. Economics Bulletin, 29 (1), 1-24.

Lardic, S., \& Mignon, V. (2006). The Impact of Oil Prices on GDP in European Countries: An Empirical Investigation Based on Asymmetric Cointegration. Energy Policy, 34 (18), 3910-3915.

Lardic, S.,\& Mignon, V. (2008). Oil prices and economic activity: An asymmetric cointegration approach. Energy Economics, 30 (3), 847-855.

Lee, K.,\& Ni, S.(2002). On the dynamic effects of oil price shocks: A study using industry level data. Journal of Monetary Economics, 49 (4), 823-852.

Lee, K., Ni, S.,\&Ratti,R. A. (1995). Oil Shocks and the Macroeconomy: The Role of Price Volatility.Energy Journal, 16, 39-56.

Lescaroux, F.,\& Mignon, V. (2009). The symposium on 'china's impact on the global economy': Measuring the effects of oil prices on china's economy: A factoraugmented vector autoregressive approach. PacificEconomic Review, 14 (3), 410-425. 
Lippi, F.,\& Nobili, A.(2009). Oil and the macroeconomy: A quantitative structural analysis. Bank of Italy working paper, No. 704.

Mankiw, G.N.(2013). Macroeconomics( $8^{\text {th }}$ ed.). Worth Publishers.

Mishkin, F.S.(2001). The Transmission Mechanism and the Role of Asset Prices in Monetary Policy. NBER Working Paper Series, Massachusetts.

Mork, K.A.(1989). Oil and macroeconomy when prices go up and down: An extension of Hamilton's results. Journal of Political Economy, 97 (3), 740744.

Nizar, M.A. (2012). Dampak Fluktuasi Harga Minyak Dunia Terhadap Perekonomian Indonesia. Bulletin Ilmiah Litbang Perdagangan, 8 (2), 189-210.

Rasche, R.H.,\& Tatom, J.A.(1977). Energy resources and potential GNP. Review, Federal Reserve Bank of St. Louis, 10-24.

Rotemberg, J.J.,\& Woodford, M. (1996). Imperfect competition and the effects of energy prices increases on economic activity. Journal of Money, Credit and Banking, 1 (28(4)), 549-577.

Rydland, S-E. (2011). An Empirical Analysis of How Oil Price Changes Influnce the Norwegian Economy. Norges handelsoyskole, Bergen.

Sims, C.A.(1980). Macroeconomics and reality. Econometrica, 48 (1), 1-48.

Tang, W., Libo, W.,\&Zhang,Z. (2010). Oil Price Shocks and Their Short- and LongTerm Effects on the Chinese Economy.Energy Economics, 32, S3-S14.

von Braun, J. (2008). Rising food prices: What should be done? EuroChoices, 7 (2), 30-35.

World Bank(2010). Boom, Bust and Up Again? Evolution, Drivers and Impact of Commodity Prices: Implications for Indonesia. http://go.worldbank.org/YY1OOD9UB0 and at www.worldbank.org/id/trade. Diakses 3 Januari 2014.

Yahya, I.(2007). Efektivitas Kebijakan Moneter Dalam Menangani Dampak Variabel Shock Eksternal Pada Rezim Nilai Tukar Mengambang Bebas: Studi Kasus Indonesia (Model Structural VAR: Periode 1997:8-2006:12). FE UI. http://lontar.ui.ac.id/file?file=digital/125854-5634-Efektivitas\%20kebijakanAnalisis.pdf

Zhang, Q.,\& Reed, M.(2008). Examining the impact of the world crude oil prices on china's agricultural commodity prices: The case of corn, soybean and pork.The Southern Agricultural Economics Association Annual Meetings, Dallas, TX, February 2-5. 